\title{
O REGIME JURÍDICO-CONSTITUCIONAL DOS DEVERES FUNDAMENTAIS
}

\author{
THE JURIDICAL-CONSTITUTIONAL REGIME OF FUNDAMENTAL DUTIES
}

\section{EL RÉGIMEN JURÍDICO-CONSTITUCIONAL DE LOS DEBERES} FUNDAMENTALES

\author{
ROGÉRIO SANTOS RAMMÊ \\ https://orcid.org/0000-0002-8396-1768 / http://lattes.cnpq.br/4320207672587245 / rogerioramme@hotmail.com \\ Centro Universitário Metodista - IPA; \\ Pontifícia Universidade Católica do Rio Grande do Sul - PUCRS \\ Porto Alegre, RS, Brasil.
}

\section{RESUMO}

$\mathrm{O}$ artigo discute o regime jurídico-constitucional dos deveres fundamentais, na perspectiva do sistema constitucional brasileiro. Objetiva delimitar as características dos deveres fundamentais, diferenciando-os de outras figuras jurídicas próximas. Busca identificar os beneficiários e os destinatários de deveres fundamentais, sua tipologia e seus princípios estruturantes e analisar questões controvertidas à respeito do tema. 0 método de pesquisa adotado é o dedutivo, amparado em pesquisa bibliográfica e jurisprudencial. Conclui que os deveres fundamentais constituem uma categoria jurídico-constitucional autônoma. Eles podem ser autônomos em sentido estrito ou associados ou conexos a direitos fundamentais. Possuem tipicidade constitucional expressa ou implícita. Impõem obrigações de conduta positivas ou negativas aos particulares e podem ter como beneficiários o Estado, indivíduos específicos, a coletividade em geral, presente ou futura e até mesmo as demais formas de vida não-humanas.

Palavras-chave: deveres fundamentais; direitos fundamentais; constitucionalismo; regime jurídico-constitucional.

\section{ABSTRACT}

The article discusses the legal-constitutional regime of fundamental duties, in the perspective of the Brazilian constitutional system. It is intended to delimit the characteristics of fundamental rights, differentiating them from other legal figures close to them. It seeks to identify the beneficiaries and recipients of the fundamental duties, their typology, their structuring principles and to analyze controversial issues on the subject. The method of research adopted is the deductive one, supported by bibliographical research and jurisprudential. Concludes that fundamental rights constitute an autonomous legal-constitutional category. They may be autonomous in the strict sense or associated with or linked to fundamental rights. They have constitutional typicity either express or implied. They impose positive or negative behavioral obligations on individuals and may have that beneficiaries the state, specific individuals, the present or future collectivity, and even other nonhuman life forms.X

Keywords: fundamental duties; fundamental rights; constitutionalism; legal-constitutional regime.

\section{RESUMEN}

El artículo analiza el régimen jurídico-constitucional de los deberes fundamentales, en la perspectiva del sistema constitucional brasileño. Tiene como objetivo delimitar las características de los deberes fundamentales, diferenciándolos de otras situaciones jurídicas cercanas. Se busca identificar a los beneficiarios ya los destinatarios de deberes fundamentales, su tipología y sus principios estructurantes y cuestiones controvertidas al respecto. El método de investigación adoptado es el deductivo, a partir da investigación bibliográfica y jurisprudencial. Se concluye que los deberes fundamentales constituyen una categoría jurídico-constitucional autónoma. Pueden ser autónomos en sentido estricto o asociados o conexos con derechos fundamentales. Poseen tipicidad constitucional expresa o implícita. Imponem obligaciones de conducta positivas o negativas a los particulares y pueden tener como beneficiarios al Estado, individuos específicos, la colectividad en general, presente o futura e incluso las demás formas de vida no humanas.

Palabras clave: deberes fundamentales; derechos fundamentales; constitucionalismo; régimen jurídicoconstitucional. 
ISSN 1981-3694

(DOI): $10.5902 / 1981369438399$

\section{SUMÁRIO}

INTRODUÇAO; 1 O RELATIVO ESQUECIMENTO DOS DEVERES FUNDAMENTAIS; 2 EQUÍVOCOS DE COMPREENSÃO RELACIONADOS AO TEMA DOS DEVERES FUNDAMENTAIS; 3 CARACTERÍSTICAS PRINCIPAIS DOS DEVERES FUNDAMENTAIS E SUAS DIMENSÕES OBJETIVA E SUBJETIVA; 4 TITULARES ATIVOS (BENEFICIÁRIOS) E TITULARES PASSIVOS (DESTINATÁRIOS) DE DEVERES FUNDAMENTAIS; 5 A TIPOLOGIA DOS DEVERES FUNDAMENTAIS; 6 DEVERES FUNDAMENTAIS E PRINCÍPIOS CONSTITUCIONAIS ESTRUTURANTES; 7 ABERTURA MATERIAL E APLICABILIDADE DOS DEVERES FUNDAMENTAIS; CONCLUSÃO; REFERÊNCIAS.

\section{INTRODUÇÃO}

De um modo geral, o constitucionalismo contemporâneo tem relegado ao tema dos deveres fundamentais um relativo desprestígio, se comparado ao desenvolvimento teóricodogmático destinado ao tema dos direitos fundamentais. Explicações para esse fenômeno são dadas pelos constitucionalistas, muitas das quais ligadas à própria noção de Estado de Direito.

Contudo, a doutrina constitucional contemporânea avança cada vez mais rumo à compreensão da autonomia estrutural e funcional dos deveres fundamentais enquanto categoria jurídica autônoma. Com isso, também as obrigações decorrentes dos deveres fundamentais, impostas aos indivíduos e à coletividade em geral, ganham maior destaque e importância. Devese salientar, porém, que muito embora a categoria jurídica dos deveres fundamentais venha despertando um relativo interesse recente na doutrina constitucional brasileira, ainda não há uma sistematização clara acerca do seu regime jurídico-constitucional.

Nesse contexto, o presente artigo traz como problema investigativo justamente a delimitação do regime jurídico-constitucional dos deveres fundamentais, na perspectiva da Constituição Federal da República de 1988. Os objetivos do trabalho são: (a) analisar as razões pelas quais o tema dos deveres fundamentais não obteve grande destaque ou interesse da doutrina constitucional contemporânea, salientando equívocos de compreensão que cercam a matéria; (b) identificar as principais características dos deveres fundamentais, diferenciando-os dos deveres passivos ou correlativos dos direitos e das outras figuras jurídicas próximas; (c) delimitar o traço distintivo entre as dimensões subjetiva e objetiva dos deveres fundamentais; (d) especificar quem são os titulares ativos (beneficiários) e titulares passivos (destinatários) de deveres fundamentais; (e) identificar a tipologia dos deveres fundamentais e seus princípios estruturantes; (f) verificar a possibilidade de uma abertura material a deveres fundamentais e a forma de sua aplicabilidade. 
ISSN 1981-3694

(DOI): $10.5902 / 1981369438399$

0 método de pesquisa adotado é o dedutivo, amparado em pesquisa bibliográfica e jurisprudencial sobre o tema investigado.

Com efeito, busca-se realizar ao longo do presente artigo, sem a pretensão de esgotar o tema dada sua amplitude e complexidade, é traçar os aspectos gerais do regime jurídico dos deveres fundamentais, à luz de aportes doutrinários e jurisprudenciais, com o intuito de contribuir para o seu estudo e desenvolvimento teórico-dogmático pela doutrina constitucional pátria.

\section{RELATIVO ESQUECIMENTO DOS DEVERES FUNDAMENTAIS}

O tema dos deveres fundamentais é, ainda, carecedor de maior desenvolvimento teórico e dogmático pela doutrina constitucional contemporânea. Isso se deve, segundo Nabais ${ }^{1}$, ao escasso desenvolvimento teórico e dogmático, no âmbito do direito público, destinado às "situações jurídico passivas", ou seja, situações que impliquem sujeições, deveres ou obrigações aos particulares. E a explicação para esse fenômeno é bastante lógica: a ideia originária de "Estado de Direito", concebida como modelo ideal de organização social no qual o poder estatal é limitado pelo direito, garantindo aos cidadãos uma esfera de liberdade e autonomia, fez com que fosse dada uma quase absoluta prioridade à reivindicação de direitos subjetivos públicos, em detrimento dos deveres que expressassem responsabilidades comunitárias. Ademais, contribuiu para o esquecimento do tema dos deveres fundamentais no constitucionalismo contemporâneo o fato de muitas das constituições ocidentais terem sido promulgadas após a queda de regimes totalitários, marcados pelo autoritarismo e pela predominância das situações jurídicas passivas dos indivíduos. ${ }^{2}$

Cabe destacar que a primeira constituição a estabelecer uma relação de deveres (em nove artigos) foi a Constituição Francesa de 1795. Peces-Barba Martínez ${ }^{3}$ afirma se tratarem somente de deveres dos cidadãos (não dos governantes), embasados nos princípios de não fazer aos outros o que não se deseja que seja feito para si próprio e fazer o bem que se deseja receber dos outros. Assim, basicamente, os deveres da Constituição Francesa de 1795 são os de servir à sociedade, submeter-se às leis, respeitar órgãos e instituições públicas, manter e

\footnotetext{
1 NABAIS, José Casalta. O dever fundamental de pagar impostos: contributo para a compreensão do estado fiscal contemporâneo. Coimbra: Almedina, 2009.

2 NABAIS, José Casalta. 0 dever fundamental de pagar impostos: contributo para a compreensão do estado fiscal contemporâneo. Coimbra: Almedina, 2009, p. 16-17.

3 PECES-BARBA MARTíNEZ, Gregório. Los deberes fundamentales. Doxa: cuadernos de filosofía del derecho. n. 4, 1987, p. 329-341.
} 
ISSN 1981-3694

(DOI): $10.5902 / 1981369438399$

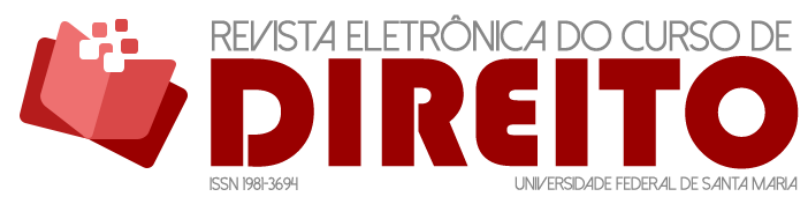

O REGIME JURÍDICO-CONSTITUCIONAL DOS DEVERES

FUNDAMENTAIS

respeitar as propriedades e defender a pátria. Para o autor, nessa primeira ocasião em que se positivam deveres constitucionais, isso é feito a serviço de uma sociedade que desconfia da liberdade e da soberania popular, a serviço dos interesses dos proprietários e, sobretudo, como contrapeso à Declaração de Direitos de 1789. Essa desconfiança com os direitos do homem e com as reivindicações progressistas por liberdades se expressou na organização política dos Estados autoritários da época (Itália, Alemanha, Portugal e Espanha), que priorizaram os deveres dos cidadãos, em detrimento dos direitos, como estratégia de poder.

Compreende-se, pois, que, como espécie de reação aos regimes totalitários e como estratégia protetiva dos cidadãos e das próprias conquistas democráticas do Ocidente contra uma nova onda totalitarista, as constituições aprovadas após a segunda guerra mundial - casos da Constituição Italiana (1947), da Lei Fundamental da República Federal da Alemanha (1949), bem como outras mais recentes como a Constituição Portuguesa (1976) e a Constituição Espanhola (1978) -, acabaram priorizando de modo praticamente exclusivo a temática dos direitos fundamentais. A consequência desse fenômeno histórico foi, nos dizeres de Nabais (2009), relegar à sombra os deveres fundamentais. Tratou-se de uma inegável "hipertrofia dos direitos"4, a qual evidenciava, por um lado, uma "herança liberal” que colocava o indivíduo como titular de prerrogativas em face do Estado, notadamente as de não-intervenção em sua esfera pessoal; e, por outro, uma falta de comprometimento dos cidadãos com a esfera coletiva. Como corolário, esse excessivo individualismo de matriz liberal que marcou por um bom tempo a noção de "Estado de Direito", veio a ser moderada no avançar histórico, com a noção de "Estado Social" e a incorporação de elementos sociais e deveres fundamentais de caráter econômico, social e cultural. ${ }^{5}$

Ao longo da história, as distorções provocadas pelos regimes totalitários de direita, como o fascismo e o nazismo, e de esquerda, como o comunismo, provocaram, como destaca Gomes $^{6}$, certo estigma à figura do dever, despindo-o do manto da responsabilidade comunitária e vinculando-o a uma noção de submissão, ou seja, algo que serve apenas para funcionalizar a existência dos indivíduos ao interesse do Estado. Entretanto, a partir da reconquista da

4 SARLET, Ingo Wolfgang. A eficácia dos direitos fundamentais: uma teoria geral dos direitos fundamentais na perspectiva constitucional. 10. ed. - Porto Alegre: Livraria do Advogado Editora, 2010, p. 226.

${ }^{5}$ NABAIS, José Casalta. O dever fundamental de pagar impostos: contributo para a compreensão do estado fiscal contemporâneo. Coimbra: Almedina, 2009, p. 59. SARLET, Ingo Wolfgang. A eficácia dos direitos fundamentais: uma teoria geral dos direitos fundamentais na perspectiva constitucional. 10. ed. Porto Alegre: Livraria do Advogado Editora, 2010, p. 227.

6 GOMES, Carla Amado. Risco e modificação do acto autorizativo concretizador de deveres de protecção do ambiente. Tese de Doutorado em Ciências Jurídico-Políticas, Faculdade de Direito. Universidade de Lisboa, Lisboa, 2007, p. 91. 
ISSN 1981-3694

(DOI): $10.5902 / 1981369438399$

democracia na Europa, após a segunda guerra mundial, essas distorções sobre os deveres passaram a perder força, sendo identificável o fenômeno, típico do Estado Social, de (re)integração do dever na esfera dos sistemas constitucionais, com o sentido de uma "liberdade responsável". ${ }^{7}$

Um exemplo emblemático desse fenômeno é a Declaração Universal dos Direitos Humanos, de 1948, formulada pela Organização das Nações Unidas (ONU), e que em seu artigo 29 afirma que "todo homem tem deveres para com a comunidade". Também é digno de nota a previsão de deveres humanos no preâmbulo do Pacto Internacional dos Direitos Econômicos, Sociais e Culturais de 1966; no artigo 32 da Convenção Americana de Direitos Humanos de 1969; e no artigo 29\%/7 da Carta Africana dos Direitos Humanos e dos Povos de 1981. Também a Carta dos Direitos Fundamentais da União Europeia, incorporada ao Tratado de Lisboa, prevê expressamente, em seu preâmbulo, que gozo dos direitos fundamentais implica deveres e responsabilidades humanas para com indivíduos, comunidades e gerações futuras. ${ }^{8}$

Com efeito, como observa Canotilho" ${ }^{9}$, "os tempos estão, hoje, maduros para uma reproblematização desta importante categoria jurídica e política." Contudo, no âmbito normativo constitucional, mesmo na perspectiva do Estado Social o tratamento que a maioria das constituições destina aos deveres fundamentais não se compara àquele destinado aos direitos fundamentais. ${ }^{10}$

No que tange especificamente à Constituição da República Federativa do Brasil isso é facilmente verificável. Inexiste um tratamento sistematizado para os deveres fundamentais, muito embora seja possível identificar a existência de deveres fundamentais espalhados de maneira assistemática no texto constitucional. Casos, por exemplo, do dever da família (pais ou responsáveis) para com a educação dos filhos (artigos 205, 208, § 3º, 227 e 229), do dever de prestar serviço militar (art. 143), ou ainda o dever imposto à coletividade de defender e preservar o meio ambiente (art. 225, caput). Segundo afirmam Vieira e Pedra ${ }^{11}$, isso se deve ao

\footnotetext{
7 GOMES, Carla Amado. Risco e modificação do acto autorizativo concretizador de deveres de protecção do ambiente. Tese de Doutorado em Ciências Jurídico-Políticas, Faculdade de Direito. Universidade de Lisboa, Lisboa, 2007, p. 91.

${ }^{8}$ SARLET, Ingo Wolfgang; FENSTERSEIFER, Tiago. Direito constitucional ambiental: constituição, direitos fundamentais e proteção do ambiente. 3. ed. São Paulo: Revista dos Tribunais, 2013, p. 229-230.

${ }^{9}$ CANOTILHO, José Joaquim Gomes. Direito Constitucional e Teoria da Constituição. 7. ed. - Coimbra: Almedina, 2003, p. 531.

10 NABAIS, José Casalta. O dever fundamental de pagar impostos: contributo para a compreensão do estado fiscal contemporâneo. Coimbra: Almedina, 2009, p. 22-23.

11 VIEIRA, Pedro Gallo; PEDRA, Adriano Sant'Ana. O rol de deveres fundamentais na Constituição como numerus apertus. Derecho y Cambio Social, n. 31, 2013, p. 2. Disponível em:
} 
ISSN 1981-3694

(DOI): $10.5902 / 1981369438399$

fato de a Constituição brasileira ter sido promulgada "sob os ecos do período militar”, razão pela qual se tornou uma Constituição repleta de direitos em resposta aos tempos passados quando imperava a falta de direitos fundamentais. A previsão dos deveres restou, portanto, enfraquecida e resumida a raros deveres expressos, sem sistematização lógica. ${ }^{12}$

Já em âmbito doutrinário, muito embora exista, como afirma Vieira de Andrade $^{13}$, uma vasta bibliografia dedicada ao tema dos deveres fundamentais, notadamente em obras desenvolvidas por autores alemães, italianos, portugueses e espanhóis, raros são os trabalhos que dispensam aos deveres fundamentais um tratamento autônomo, ou mesmo que se voltam à elaboração de uma teoria geral dos deveres fundamentais. Na mesma linha, Sarlet ${ }^{14}$ salienta que no Brasil também são escassos os casos de maior desenvolvimento doutrinário e jurisprudencial sobre a temática dos deveres fundamentais. ${ }^{15}$

0 escasso desenvolvimento teórico dedicado a analisar o regime jurídico-constitucional dos deveres fundamentais, para Nabais ${ }^{16}$, se deve à concepção liberal, já superada, e anterior ao surgimento da noção de Estado Social, que restringia os deveres fundamentais dentro da temática dos limites dos direitos fundamentais. Limites imanentes, restrições ou colisões de direitos. Essa perspectiva, bem como aquela que concebe os deveres fundamentais como mera expressão da soberania estatal, definitivamente, não são adequadas para compreender os deveres fundamentais enquanto categoria jurídico-constitucional. Por essa razão, faz-se necessário formular uma tentativa de sistematização, a partir da perspectiva jurídicoconstitucional, da categoria dos deveres fundamentais.

Muito embora o tema dos deveres fundamentais se insira, juntamente com os direitos fundamentais, naquilo que Nabais define como "(sub)constituição do indivíduo", isso não significa que a temática dos deveres fundamentais se ou esteja esgote diluída no objeto de estudo dos direitos fundamentais. Ao contrário, o que se procurará demonstrar, a seguir, é que

https://www.derechoycambiosocial.com/revista031/O_ROL_DE_DEVERES_FUNDAMENTAIS.pdf.

Acesso em: 12 set. 2020.

12 DIMOULIS, Dimitri; MARTINS, Leonardo. Deveres Fundamentais. In: LEITE, George Salomão; SARLET, Ingo Wolfgang; CARBONELL, Miguel (Coords.). Direitos, deveres e garantias fundamentais. Salvador: Juspodvium, 2011, p. 327.

13 VIEIRA DE ANDRADE, José Carlos. Os direitos fundamentais na Constituição Portuguesa de 1976. $5^{\mathrm{a}}$ ed. - Coimbra: Almedina, 2012, p. 149.

14 SARLET, Ingo Wolfgang. A eficácia dos direitos fundamentais: uma teoria geral dos direitos fundamentais na perspectiva constitucional. 10. ed. - Porto Alegre: Livraria do Advogado Editora, 2010, p. 226.

${ }^{15}$ Curiosamente, a temática dos deveres fundamentais vem sendo desenvolvida no Brasil com relativa profundidade quando associada à perspectiva de algum dever fundamental específico, sendo os melhores exemplos os deveres fundamentais de proteção do ambiente e de pagar impostos.

${ }^{16}$ NABAIS, José Casalta. O dever fundamental de pagar impostos: contributo para a compreensão do estado fiscal contemporâneo. Coimbra: Almedina, 2009, p. 24-25. 
ISSN 1981-3694

(DOI): $10.5902 / 1981369438399$

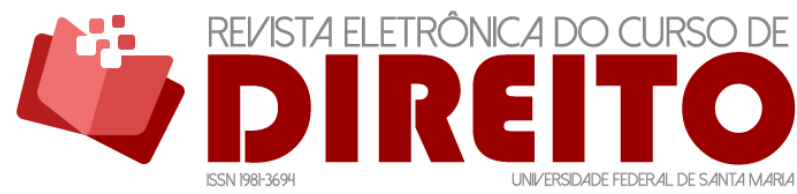

os deveres fundamentais devem ser compreendidos como categoria jurídica autônoma, muito embora os inegáveis pontos de contato com o tema dos direitos fundamentais.

\section{EQUÍVOCOS DE COMPREENSÃO RELACIONADOS AO TEMA DOS DEVERES FUNDAMENTAIS}

Pelo menos duas são as perspectivas equivocadas na compreensão e tratamento destinado ao tema dos deveres fundamentais: a primeira é aquela típica das teorias liberais (relativas ao homem, à sociedade e ao Estado) que integra ou esgota o tema dos deveres fundamentais na categoria dos direitos fundamentais; a segunda, também inadequada, é a que concebe os deveres fundamentais como mera expressão da soberania estatal, tal como ocorre, por exemplo, com as teorias funcionalizantes dos direitos fundamentais, típicas dos Estados totalitários, que subordinam os direitos aos deveres. ${ }^{17}$

O equívoco da primeira perspectiva (que integra ou esgota o estudo dos deveres fundamentais na temática dos direitos fundamentais) decorre da compreensão dos deveres fundamentais como meros limites aos direitos fundamentais. Essa percepção é claramente equivocada. Muito embora os direitos fundamentais não sejam limitados ou limitáveis apenas por razões de ordem subjetiva, como as liberdades de outrem igualmente asseguradas pelo ordenamento jurídico-constitucional, também razões de ordem puramente objetiva podem servir de suporte a sua limitação, caso dos limites ou restrições especialmente concebidos pela Constituição, os quais, porém, não se confundem com os deveres fundamentais. ${ }^{18}$ A confusão decorre sobretudo do fato de que também são razões de ordem objetiva, atreladas a uma noção de responsabilidade comunitária dos indivíduos que dão suporte aos deveres fundamentais. Contudo, é a autonomia estrutural e funcional do regime jurídico dos deveres fundamentais o que os distingue substancialmente dos limites ou restrições a direitos fundamentais especialmente concebidos pela Constituição.

Isso não significa, porém, que os deveres fundamentais deixem de se relacionar com os direitos fundamentais, ainda que de forma autônoma, afinal ambos compõem o que o estatuto constitucional do indivíduo e concretizam o princípio da dignidade da pessoa humana. Tarefa que não se limita ao estabelecimento de direitos fundamentais, mas também impõe o

\footnotetext{
17 NABAIS, José Casalta. O dever fundamental de pagar impostos: contributo para a compreensão do estado fiscal contemporâneo. Coimbra: Almedina, 2009, p. 28-35.

18 NABAIS, José Casalta. 0 dever fundamental de pagar impostos: contributo para a compreensão do estado fiscal contemporâneo. Coimbra: Almedina, 2009, p. 31.
} 
ISSN 1981-3694

(DOI): $10.5902 / 1981369438399$

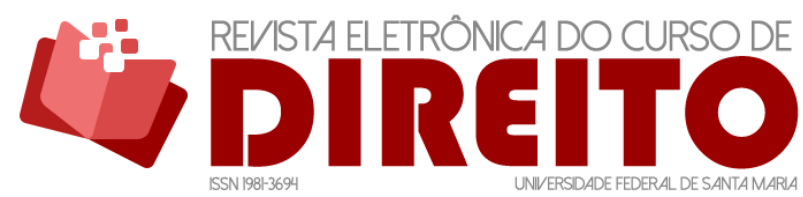

O REGIME JURÍDICO-CONSTITUCIONAL DOS DEVERES

FUNDAMENTAIS

estabelecimento de determinadas posições assertórias de comportamento, lastreadas em certos valores comunitários e dotadas de regime jurídico próprio, que são, justamente, os deveres fundamentais. ${ }^{19}$ Portanto, devem-se rejeitar as ideias de que os deveres fundamentais sejam apenas: (a) a concretização legal de limites à liberdade assegurada pelos direitos fundamentais; e (b) em essência, limites aos direitos fundamentais. ${ }^{20}$

Dito de outro modo, pode uma constituição estabelecer diretamente ou autorizar restrições legislativas a posições jusfundamentais de vantagem, tal como faz a Constituição brasileira ao determinar que a propriedade atenda sua função social (art. 5, XXIII), conferindo competência à União para desapropriar por interesse social, para fins de reforma agrária, mediante prévia e justa indenização, a propriedade rural que não a esteja cumprindo (art. 184, caput). Trata-se de uma restrição ao direito fundamental de propriedade em nome de valores constitucionais e do interesse coletivo. Contudo, tal restrição não caracteriza um dever fundamental propriamente dito, porquanto os deveres fundamentais se notabilizam pela prescrição constitucional de "obrigações de conduta, positiva ou negativa, oponíveis à generalidade dos cidadãos, ou a certas categorias". ${ }^{21}$

No caso específico da função social da propriedade, porém, cumpre tecer algumas considerações, com amparo na doutrina pátria, que vão no sentido contrário ao do exemplo dado acima. Para Sarlet ${ }^{22}$, a função social (e ecológica) da propriedade insere-se no rol dos deveres fundamentais conexos, pela sua íntima conexão com o direito fundamental de propriedade. Ainda sobre o tema, comentando essa questão e trazendo a lume a divergência referida acima, merece destaque a observação de Basso ${ }^{23}$ :

[...] fica claro que deve ser separada a noção de deveres fundamentais daquela de limitações ou restrições aos direitos fundamentais, posto que aqueles se submetem a um regime, que aqui se busca expor, inclusive com discussão sobre sua eficácia e rigidez, ao passo que as limitações a direitos fundamentais submetem-se a outro regime, como uma questão acessória do próprio regime dos direitos fundamentais. Por exemplo, a função social tida como limite do direito de propriedade é um acessório deste e com ele se extingue, não havendo que se

\footnotetext{
19 BASSO, Joaquim. Notas sobre o regime jurídico dos deveres fundamentais no ordenamento jurídico brasileiro. Revista Direito UFMS, v. 1, n. 2, Campo Grande, MS, 2016, p. 95.

20 NABAIS, José Casalta. 0 dever fundamental de pagar impostos: contributo para a compreensão do estado fiscal contemporâneo. Coimbra: Almedina, 2009, p. 31-32.

21 GOMES, Carla Amado. Risco e modificação do acto autorizativo concretizador de deveres de protecção do ambiente. Tese de Doutorado em Ciências Jurídico-Políticas, Faculdade de Direito. Universidade de Lisboa, Lisboa, 2007, p. 92.

22 SARLET, Ingo Wolfgang. A eficácia dos direitos fundamentais: uma teoria geral dos direitos fundamentais na perspectiva constitucional. 10. ed. - Porto Alegre: Livraria do Advogado Editora, 2010, p. 228.

${ }^{23}$ BASSO, Joaquim. Notas sobre o regime jurídico dos deveres fundamentais no ordenamento jurídico brasileiro. Revista Direito UFMS, v. 1, n. 2, Campo Grande, MS, 2016, p. 95.
} 
ISSN 1981-3694

(DOI): $10.5902 / 1981369438399$

questionar sua eficácia (se precisa de regulamentação, por exemplo) ou rigidez (se pode ser extirpada do ordenamento). Já a função social encarada como dever fundamental da propriedade submeter-se-á ao regime de rigidez e eficácia desses deveres.

Muito embora tendamos a concordar com Gomes, ambas as posições são defensáveis e a discordância supra referida apenas demonstra a necessidade de um aprofundamento sistemático do regime dos deveres fundamentais na ordem constitucional brasileira, para bem distinguir os deveres fundamentais das limitações ou restrições constitucionais a direitos fundamentais.

Feitas as observações acima, avança-se sobre os motivos que demonstram o equívoco da perspectiva que dissolve o conteúdo dos direitos fundamentais nos deveres fundamentais. Tal entendimento acarreta uma contradição destacada por Nabais $^{24}$ : acaba com a posição ativa ou passiva do indivíduo, anulando-o enquanto pessoa livre e responsável, e colocando em primeiro plano o poder e a organização política e econômica estatais. Ressalte-se que a funcionalização, refutada por Nabais, é aquela que converte os direitos fundamentais, para seus titulares passivos, em deveres fundamentais. Afinal, para os seus titulares passivos os direitos fundamentais, em razão da sua complexa estrutura, podem constituir: deveres de abstenção do Estado; deveres a prestações protetivas do Estado, aqui inseridas as prestações organizacionais, procedimentais ou mesmo processuais. Bem como deveres de abstenção dos particulares em geral, em decorrência da eficácia horizontal dos direitos fundamentais nas relações privadas.

Essas e outras figuras que não se confundem com os deveres fundamentais serão melhor analisadas a seguir, buscando identificar os traços característicos definidores do regime jurídico dos deveres fundamentais.

\section{CARACTERÍSTICAS PRINCIPAIS DOS DEVERES FUNDAMENTAIS E SUAS DIMENSÕES OBJETIVA E SUBJETIVA}

O primeiro aspecto a ser destacado com relação dos deveres fundamentais, relaciona-se com sua autonomia enquanto categoria jurídico-constitucional. Com isso se quer afirmar que os deveres fundamentais constituem, em verdade, e assim devem ser compreendidos, uma categoria jurídica própria, com um regime jurídico-constitucional específico.

Nesse sentido é que se afirma a autonomia dos deveres fundamentais, muito embora, como se demonstrará mais adiante, eles possam, internamente, ser divididos em deveres

${ }^{24}$ NABAIS, José Casalta. 0 dever fundamental de pagar impostos: contributo para a compreensão do estado fiscal contemporâneo. Coimbra: Almedina, 2009, p. 32. 
ISSN 1981-3694

(DOI): $10.5902 / 1981369438399$

fundamentais essencialmente autônomos e deveres fundamentais conexos ou associados à direitos fundamentais. Os deveres fundamentais são expressões de valores ou interesses comunitários constitucionalmente reconhecidos, que, mesmo quando associados ou conexos a direitos, representam, nos dizeres de Vieira de $A_{n d r a d e}{ }^{25}$, uma "realidade autónoma e exterior a cada um deles, embora, na medida em que são explicitações de valores comunitários, possam fundamentar a limitação dos direitos fundamentais em geral, designadamente das liberdades."

Com efeito, cabe destacar que os valores comunitários que justificam a existência dos deveres fundamentais, acabam por moderar o excessivo individualismo atrelado à noção de Estado de Direito, contemplando, na perspectiva de um Estado Social, deveres econômicos, sociais, culturais e ambientais. ${ }^{26}$ Tratam-se, assim, de valores comunitários que se contrapõem aos valores e interesses individuais os quais se afirmam na figura dos direitos fundamentais, 0 que não impede que os deveres fundamentais integrem a matéria dos direitos fundamentais em sentido amplo, se apresentando como "quase direitos fundamentais da comunidade em face do indivíduo". ${ }^{27}$

Por essa mesma razão é que se afirma a forte vinculação existente, muito embora não exauriente, entre o tema dos deveres fundamentais e a dimensão objetiva dos direitos fundamentais. Mas deve-se ressaltar que tal vinculação relaciona-se aos valores comunitários que a dimensão objetiva dos direitos fundamentais consagra e não propriamente aos desdobramentos jurídicos decorrentes. Afinal, em essência, a dimensão objetiva dos direitos fundamentais acarreta uma mais-valia jurídica à dimensão subjetiva desses mesmos direitos, a saber: (a) a eficácia irradiante dos direitos fundamentais, a exigir, no plano da aplicação e interpretação do direito infraconstitucional, uma interpretação conforme os direitos fundamentais; (b) a eficácia horizontal, já mencionada, que implica a irradiação dos efeitos dos direitos fundamentais no âmbito das relações privadas e não apenas em face dos poderes públicos; (c) os deveres de proteção do Estado em matéria de direitos fundamentais; e (d) as

\footnotetext{
${ }^{25}$ VIEIRA DE ANDRADE, José Carlos. Os direitos fundamentais na Constituição Portuguesa de 1976. 5. ed. - Coimbra: Almedina, 2012, p. 149.

26 SARLET, Ingo Wolfgang. A eficácia dos direitos fundamentais: uma teoria geral dos direitos fundamentais na perspectiva constitucional. 10. ed. Porto Alegre: Livraria do Advogado Editora, 2010, p. 227.

27 NABAIS, José Casalta. 0 dever fundamental de pagar impostos: contributo para a compreensão do estado fiscal contemporâneo. Coimbra: Almedina, 2009, p. 38.
} 
ISSN 1981-3694

(DOI): $10.5902 / 1981369438399$

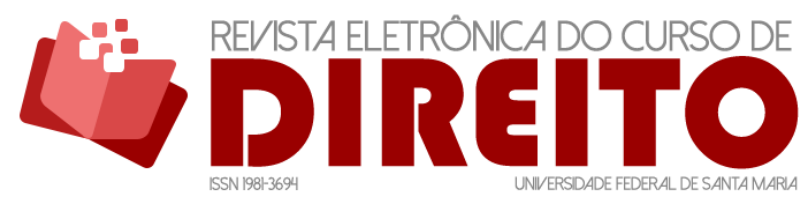

O REGIME JURÍDICO-CONSTITUCIONAL DOS DEVERES

FUNDAMENTAIS

consequências nos planos organizacional e procedimental que auxiliem na efetivação e proteção dos direitos fundamentais, grifo nosso. ${ }^{28}$

Deve ser compreendido, porém, que a autonomia dos deveres fundamentais não implica uma absoluta desconexão com a categoria dos direitos fundamentais. Primeiramente, porque todos os deveres fundamentais limitam, pela sua natureza, a esfera de liberdade dos indivíduos. Nesse sentido, a partir da conformação do conteúdo dos deveres fundamentais e dos valores comunitários que os amparam, estaria justificada, como já salientado, uma interpretação restritiva do conteúdo de um direito fundamental. Essa restrição, porém, jamais poderá ser total, pois, como destaca Sarlet ${ }^{29}$, "[...] o núcleo essencial do direito fundamental ('limite dos limites') restará sempre preservado." Assim, reafirma-se, os deveres fundamentais atuam como fundamento para a restrição de direitos fundamentais. ${ }^{30}$ Semelhante entendimento vem sendo adotado na jurisprudência recente do Superior Tribunal de Justiça:

RECURSO ESPECIAL. EMBARGOS DE DECLARAÇÃO. ALEGAÇÃO DE OMISSÃO. FRAUDE AO CARÁTER COMPETITIVO E CORRUPÇÃO PASSIVA. ATIPICIDADE. NÃO OCORRÊNCIA. OBJETIVO DE PREQUESTIONAMENTO DE MATÉRIA CONSTITUCIONAL. [...] é possível assimilar o novo posicionamento da Suprema Corte, forte na necessidade de se empreender, na interpretação e aplicação de qualquer norma jurídica que interfira com a liberdade, uma visão também objetiva dos direitos fundamentais, a qual não somente legitima eventuais e necessárias restrições às liberdades públicas do indivíduo, em nome de um interesse comunitário prevalente, mas também a própria limitação do conteúdo e do alcance dos direitos fundamentais - preservando-se, evidentemente, o núcleo essencial de cada direito - que passam a ter, como contraponto, correspondentes deveres fundamentais. (STJ, EDcl no REsp 1484415/DF, Rel. Ministro Rogerio Schietti Cruz, Sexta Turma, DJe 14/04/2016). (Grifo do autor)

Por conseguinte, os deveres fundamentais, muito embora também sejam expressões de valores de ordem objetiva, possuem um regime jurídico próprio que guarda sintonia porém não se esgota no regime jurídico dos direitos fundamentais. ${ }^{31}$ É justamente isso que evidencia a autonomia dos deveres fundamentais enquanto categoria jurídico-constitucional e que permite diferenciá-los dos deveres passivos ou correlativos dos direitos e das outras figuras jurídicas

28 SARLET, Ingo Wolfgang. A eficácia dos direitos fundamentais: uma teoria geral dos direitos fundamentais na perspectiva constitucional. 10. ed. Porto Alegre: Livraria do Advogado Editora, 2010, p. $142-151$.

29 SARLET, Ingo Wolfgang. A eficácia dos direitos fundamentais: uma teoria geral dos direitos fundamentais na perspectiva constitucional. 10. ed. Porto Alegre: Livraria do Advogado Editora, 2010, p. 231.

30 VIEIRA DE ANDRADE, José Carlos. Os direitos fundamentais na Constituição Portuguesa de 1976. 5. ed. Coimbra: Almedina, 2012, p. 159.

31 NABAIS, José Casalta. A face oculta dos direitos fundamentais: os deveres e os custos dos direitos. Revista da AGU, Brasília, v.1, 2001, p. 77. 
ISSN 1981-3694

(DOI): $10.5902 / 1981369438399$

próximas, mas que com eles não se confundem. Em síntese, e com apoio em Nabais ${ }^{32}$, afirma-se que não são deveres fundamentais:

(a) os deveres constitucionais de cunho organizacional e funcional, os quais não integram o estatuto constitucional do indivíduo, mas sim o estatuto constitucional do poder político estatal, ou seja, a organização política do Estado, tais como os deveres constitucionais dos órgãos e dos ocupantes de cargos públicos e políticos em geral no exercício de suas funções típicas ou atípicas;

(b) os limites dos direitos fundamentais, os quais abrangem tanto as concretizações constitucionais de restrições ou âmbito máximo de conteúdo dos direitos fundamentais (limites imanentes), quanto as regulamentações para o exercício dos direitos fundamentais, que podem condicioná-los a um determinado procedimento e, portanto, de certa forma, restringir sua exigibilidade. Os deveres fundamentais, contudo, com eles não se confundem, podendo no máximo revelar a existência de limites imanentes ao exercício de um direito fundamental, ou seja, formas de exercício do direito incompatíveis com o dever fundamental, limitando o âmbito de proteção do direito fundamental;

(c) os deveres correlativos ou relacionais de direitos fundamentais, que são o lado passivo dos direitos fundamentais, integrando, portanto, o regime jurídico destes, tais como: (1) relativamente ao Estado, o dever de abstenção, não ingerência ou não perturbação ao exercício de direitos fundamentais; o dever de proteção dos direitos fundamentais contra a possível agressão ou ingerência de terceiros; o dever de proteção objetiva contra afetações indiretas sobre os direitos fundamentais, aqui compreendida a remoção de obstáculos à realização das condições fáticas para o seu exercício. Os deveres organizacionais procedimentais e processuais para sua exequibilidade; os deveres de proteção do Estado em matéria de direitos sociais destinados ao legislador, tanto de cunho positivo (concretização do conteúdo dos direitos sociais, quando minimamente concretizados no plano constitucional), quanto de cunho negativo (não afetar o nível de concretização legal obtido sem justo motivo); e, (2) relativamente aos particulares, o dever de não ingerência nos direitos fundamentais de outrem e o dever de respeito aos direitos fundamentais nas relações entre os particulares (Drittwirkung);

(d) os deveres de tolerância decorrentes das funções exercidas pelos poderes estatais (Legislativo, Executivo e Judiciário), que impõem aos indivíduos um estado de sujeição, de

32 NABAIS, José Casalta. O dever fundamental de pagar impostos: contributo para a compreensão do estado fiscal contemporâneo. Coimbra: Almedina, 2009, p. 74-87. 
ISSN 1981-3694

(DOI): $10.5902 / 1981369438399$

obediência, aos efeitos que decorrem do exercício dos poderes constitucionais do Estado, os quais também não integram o estatuto constitucional do indivíduo;

(e) os ônus constitucionais, que embora exijam certo vínculo de vontade, não acarretam a imposição de uma obrigação de conduta, seja positiva ou negativa (fazer ou não fazer algo) como ocorre nos deveres fundamentais, mas, diferentemente, impõem ao seu destinatário a necessidade prática de realizar determinado ato ou adotar certo comportamento para obter um efeito jurídico favorável ou para não perder um efeito jurídico já produzido que the seja útil (v.g. o ônus de demonstrar a insuficiência de recursos para obter assistência jurídica integral e gratuita - AJG - previsto no art. 5, LXXIV, CF/88; o ônus de alegar imperativo de consciência por razão de crença religiosa ou convicção filosófica ou política, para se eximir de realizar o serviço militar obrigatório, prestando serviço alternativo, previsto no art. 143 , § $1^{\circ}$, da CF/88), grifo nosso.

Buscar-se-á, a seguir, identificar e sistematizar as outras principais características dos deveres fundamentais, além da autonomia já referida, com o intuito de facilitar sua compreensão e construir uma definição conceitual clara. São elas:

(a) tipicidade constitucional: trata-se de categoria jurídica cujo fundamento jurídico reside na Constituição, sendo necessária uma previsão expressa ou implícita no texto constitucional para o reconhecimento de um dever fundamental. Obedecem, portanto, ao princípio da tipicidade (numerus clausus), não se podendo, conforme entendimento majoritário, admitir uma abertura material a deveres fundamentais, sem assento constitucional, ou mesmo simplesmente com base no reconhecimento de uma cláusula de deverosidade social porventura presente no texto constitucional. ${ }^{33}$ Poderá haver, porém, deveres positivados no plano infraconstitucional e que, do ponto de vista material, possuam traços de fundamentalidade em razão dos valores comunitários que consagram, mas que, por ausência de base constitucional, devem ser considerados meros deveres legais;

(b) posições jurídicas passivas: os deveres fundamentais expressam a dependência dos indivíduos junto ao Estado e à comunidade, ao contrário do que ocorre com os direitos fundamentais que expressam a primazia dos indivíduos em face do Estado. 0 que se pretende afirmar nesse particular é que os deveres fundamentais exprimem, em essência, o lado passivo da relação jurídica fundamental entre o indivíduo e o Estado ou comunidade, e que tem no indivíduo seu titular. Não se está a afirmar, portanto, que os deveres fundamentais expressam

${ }^{33}$ NABAIS, José Casalta. O dever fundamental de pagar impostos: contributo para a compreensão do estado fiscal contemporâneo. Coimbra: Almedina, 2009, p. 62. 
ISSN 1981-3694

(DOI): $10.5902 / 1981369438399$

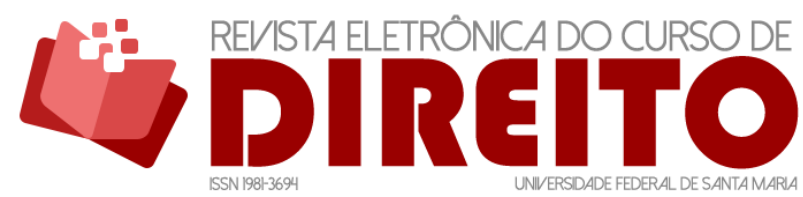

O REGIME JURÍDICO-CONSTITUCIONAL DOS DEVERES

FUNDAMENTAIS

uma relação de sujeição que imponha aos indivíduos comportamentos meramente negativos (inércia, omissão, abstenção etc.). Ao contrário, os deveres fundamentais implicam obrigações de conduta positivas ou negativas aos seus titulares. Com isso, diferenciam-se os deveres fundamentais das demais posições jurídicas passivas constitucionalmente impostas aos indivíduos, como ocorre com os deveres correlativos de direitos fundamentais, e que, como já destacado, caracterizam verdadeiros deveres de omissão (abstenção ou não perturbação), mas não deveres fundamentais propriamente ditos; ${ }^{34}$

(c) posições jurídicas subjetivas e individuais: os deveres fundamentais se caracterizam por serem posições subjetivamente imputadas aos indivíduos pela própria constituição, determinando ou tornando determinável seu comportamento nas relações intersubjetivas. São decorrência de disposições constitucionais que, expressa ou implicitamente, investem os indivíduos em posições subjetivas que vão se constituir em obrigações de conduta com conteúdo positivo ou negativo. Mesmo quando um dever fundamental específico impõe determinado comportamento à coletividade. Tal como ocorre, a título de exemplo, no artigo 225, caput, da Constituição brasileira, seu destinatário continua sendo o indivíduo, como elemento integrante da coletividade. Isso não impede ou inviabiliza que as pessoas jurídicas, mesmo de natureza pública, venham a ser reconhecidas como destinatárias de deveres fundamentais, obviamente quando compatíveis com sua natureza; ${ }^{35}$

(d) posições jurídicas permanentes (rígidas): os deveres fundamentais tem caráter permanente, não se sujeitando a restrições injustificadas de conteúdo ou mesmo supressão, seja pelo legislador ordinário seja em sede de revisão constitucional. ${ }^{36} \mathrm{~A}$ intangibilidade do conteúdo essencial dos deveres fundamentais justifica-se por eles terem, assim como os direitos fundamentais, fundamento lógico na dignidade da pessoa humana, e qualquer modificação que venha a atingir o conteúdo essencial dos deveres fundamentais acabaria também por violar a dignidade humana. Pode-se afirmar, portanto, que a regra constitucional contida no art. $60, \S 4^{\circ}$,

\footnotetext{
${ }^{34}$ NABAIS, José Casalta. 0 dever fundamental de pagar impostos: contributo para a compreensão do estado fiscal contemporâneo. Coimbra: Almedina, 2009, p. 65-67; GOMES, Carla Amado. Risco e modificação do acto autorizativo concretizador de deveres de protecção do ambiente. Tese de Doutorado em Ciências Jurídico-Políticas, Faculdade de Direito. Universidade de Lisboa, Lisboa, 2007, p. 92; SARLET, Ingo Wolfgang. A eficácia dos direitos fundamentais: uma teoria geral dos direitos fundamentais na perspectiva constitucional. 10. ed. Porto Alegre: Livraria do Advogado Editora, 2010, p. 228-229.

35 NABAIS, José Casalta. 0 dever fundamental de pagar impostos: contributo para a compreensão do estado fiscal contemporâneo. Coimbra: Almedina, 2009, p. 71.

${ }^{36}$ NABAIS, José Casalta. 0 dever fundamental de pagar impostos: contributo para a compreensão do estado fiscal contemporâneo. Coimbra: Almedina, 2009, p. 72; BASSO, Joaquim. Notas sobre o regime jurídico dos deveres fundamentais no ordenamento jurídico brasileiro. Revista Direito UFMS, v. 1 , n. 2 , Campo Grande, MS, 2016, p. 102.
} 
ISSN 1981-3694

(DOI): $10.5902 / 1981369438399$

IV, da CF/88, que veda expressamente propostas de emendas constitucionais tendentes a abolir os direitos e garantias fundamentais, muito embora não faça referência específica aos deveres fundamentais, aplica-se integralmente ao seu regime jurídico, já que os deveres fundamentais integram o estatuto constitucional do indivíduo;

(e) posições jurídicas essenciais: os deveres fundamentais revelam valores comunitários de elevado significado, os quais podem dizer respeito tanto à sua existência, subsistência ou funcionamento à luz do projeto jurídico-político constitucional. Estabelecem o quinhão de cada indivíduo, exigido pela constituição, para concretizar os valores comunitários que os fundamentam ${ }^{37}$, grifo nosso.

Como destacado, porém, nem todas as posições jurídico-passivas previstas na Constituição Federal de 1988 são deveres fundamentais típicos, entendidos como categoria jurídica própria, devendo ser excluídas as posições jurídico-passivas que caracterizam as figuras afins, anteriormente referidas, que não se confundem com deveres fundamentais.

Com efeito, analisando-se as características principais dos deveres fundamentais, identifica-se a existência de uma dimensão subjetiva nos deveres fundamentais, a qual se consubstancia em "posições de desvantagem ou passivas dos indivíduos para com o Estado exigidas por interesses públicos gerais". ${ }^{38}$ Ou seja, os deveres fundamentais exprimem posições subjetivas dos indivíduos, as quais, como já salientado vão se constituir em obrigações de conduta com conteúdo positivo ou negativo. Entretanto, os efeitos jurídicos dos deveres fundamentais não se esgotam na sua dimensão subjetiva. Tal como ocorre com os direitos fundamentais, também os deveres fundamentais possuem uma dimensão objetiva que se revela, nitidamente, em dois planos: o funcional e o estrutural.

No plano funcional, a dimensão objetiva dos deveres fundamentais estabelece uma espécie de tutela jurídica direta de valores comunitários, os quais ultrapassam a esfera puramente individual, mesmo que por trás desses valores comunitários esteja a tutela da dignidade humana. Estabelece, portanto, tarefas que devem ser compartilhadas por todos. Em síntese, no plano funcional os deveres fundamentais são expressões da responsabilidade comunitária dos cidadãos. Mas não só isso. Eles também orientam a concretização legal de tarefas políticas fundamentais de ordem econômica, social, cultural e ambiental, projetadas pela constituição.

\footnotetext{
37 NABAIS, José Casalta. O dever fundamental de pagar impostos: contributo para a compreensão do estado fiscal contemporâneo. Coimbra: Almedina, 2009, p. 73.

${ }^{38}$ NABAIS, José Casalta. 0 dever fundamental de pagar impostos: contributo para a compreensão do estado fiscal contemporâneo. Coimbra: Almedina, 2009, p. 96.
} 
ISSN 1981-3694

(DOI): $10.5902 / 1981369438399$

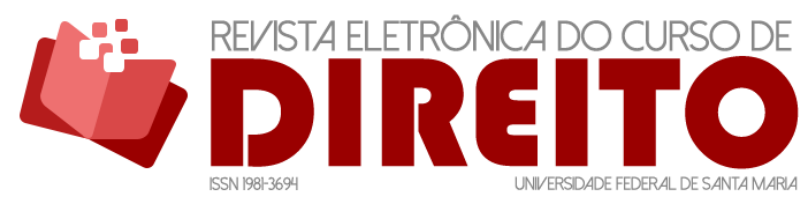

O REGIME JURÍDICO-CONSTITUCIONAL DOS DEVERES

FUNDAMENTAIS

Já no plano estrutural, a dimensão objetiva dos deveres fundamentais estabelece, à semelhança do que também ocorre com os direitos fundamentais, uma mais-valia jurídica, ou seja, os efeitos jurídicos decorrentes das normas constitucionais que estabelecem deveres fundamentais não se restringem à esfera jurídica dos seus destinatários. A esse respeito, destacam-se o efeito invalidante das leis e atos das autoridades que violem a constituição, o efeito interpretativo, conforme a constituição, e o efeito restritivo a direitos, liberdades, e garantias juridicamente protegidos. Deve-se ressaltar, ainda, haver entendimento acerca da possibilidade de, em determinadas situações, tal como ocorre nos chamados direitos-deveres, atribuir-se um efeito externo, horizontal aos deveres fundamentais. ${ }^{39}$ Aliás, Canotilho ${ }^{40}$ também reconhece essa possibilidade quando afirma ser possível falar-se em "deveres fundamentais entre cidadãos". Afinal, trate-se de deveres fundamentais essencialmente autônomos ou tratese de deveres fundamentais conexos ou associados a direitos fundamentais, ambos vinculam horizontalmente o indivíduo (destinatário do dever) à comunidade estatal na qual ele se insere. ${ }^{41}$

\section{TITULARES ATIVOS (BENEFICIÁRIOS) E TITULARES PASSIVOS (DESTINATÁRIOS) DE DEVERES FUNDAMENTAIS}

Os beneficiários de deveres fundamentais são aqueles sujeitos que detêm a sua titularidade ativa, ou seja, aqueles que irão se beneficiar com o cumprimento dos deveres fundamentais. Já os titulares passivos de deveres fundamentais são os indivíduos a quem se impõem as obrigações decorrentes do dever, ou seja, os seus destinatários.

Por refletirem valores comunitários da mais alta importância, os deveres fundamentais são, segundo Nabais ${ }^{42}$, "expressão da estadualidade no seu mais alto nível". Por essa razão, e em certa medida, o Estado é o titular ativo (beneficiário) número um de todos os deveres fundamentais, por serem eles deveres para com a comunidade estatal. Contudo, mesmo que assim o seja, no âmbito das relações intersubjetivas que decorrem dos deveres fundamentais verifica-se que tanto a coletividade em geral quanto determinadas categorias ou grupos de

39 NABAIS, José Casalta. O dever fundamental de pagar impostos: contributo para a compreensão do estado fiscal contemporâneo. Coimbra: Almedina, 2009, p. 99.

40 CANOTILHO, José Joaquim Gomes. Direito Constitucional e Teoria da Constituição. 7. ed. Coimbra: Almedina, 2003, p. 536.

${ }^{41}$ ANTUNES, Tiago. Ambiente: Um direito, mas também um dever. In: PINHEIRO, Luís de Lima; VICENTE, Dário Moura; MIRANDA, Jorge (Coords.). Estudos em memória do Professor Doutor Antônio Marques dos Santos, v. II. Coimbra: Almedina, 2005, p. 650.

42 NABAIS, José Casalta. 0 dever fundamental de pagar impostos: contributo para a compreensão do estado fiscal contemporâneo. Coimbra: Almedina, 2009, p. 105. 
ISSN 1981-3694

(DOI): $10.5902 / 1981369438399$

pessoas titulares de direitos fundamentais podem ser considerados beneficiários de certos deveres fundamentais. Até mesmo aquelas categorias tradicionalmente excluídas do âmbito de proteção dos direitos fundamentais, por lhes faltar reconhecimento de personalidade jurídica própria, podem ser incluídos no rol dos beneficiários de deveres fundamentais. Caso, por exemplo, do dever fundamental ecológico que tem como beneficiários as demais formas de vida não humanas, as futuras gerações e a comunidade global. ${ }^{43}$

Para identificar os titulares ativos (beneficiários) e os titulares passivos (destinatários) de deveres fundamentais, Nabais ${ }^{44}$ propõe uma divisão por categoria de deveres fundamentais bastante elucidativa. A primeira categoria é a dos deveres fundamentais cívico-políticos (ou clássicos), os quais abrangem os deveres fundamentais intimamente associados à existência, ao funcionamento econômico e ao funcionamento democrático da comunidade estatal, sendo, portanto, pressupostos para o próprio Estado Democrático de Direito. Os melhores exemplos são os deveres fundamentais de defesa da pátria, de pagar impostos, de prestação do serviço militar e de voto. ${ }^{45}$ Essa categoria de deveres fundamentais tem como beneficiária a própria comunidade estatal que usufrui de um Estado democrático, soberano, organizado e com estabilidade econômica para o desempenho de suas tarefas essenciais, grifo nosso.

A segunda categoria é a dos deveres fundamentais cujo beneficiário é uma categoria ou grupo de pessoas titulares de direitos fundamentais, grifo nosso. Não se trata aqui de deveres correlativos ao direito fundamental respectivo, mas um dever fundamental propriamente dito, dotado de autonomia. Um bom exemplo dessa categoria é o dever dos pais de manutenção e educação dos filhos. Segundo Medeiros ${ }^{46}$, os deveres fundamentais desse grupo, exprimem uma exigência comunitária autônoma imposta pelo Estado para "compensar a debilidade da realização daqueles direitos em razão da fragilidade de seus titulares." Nabais ${ }^{47}$ insere aqui também os deveres fundamentais que, em certa medida, se apresentam como deveres para com o próprio destinatário, tal como ocorre no dever de defender e promover a saúde própria, a qual integra a saúde coletiva e, portanto, representa um valor jurídico-constitucional dirigido a cada indivíduo.

\footnotetext{
${ }^{43}$ RAMMÊ, Rogério Santos. O dever fundamental ecológico e a proteção dos serviços ecossistêmicos. Curitiba: Editora Appris, 2019, p. 127-128.

${ }^{44}$ NABAIS, José Casalta. 0 dever fundamental de pagar impostos: contributo para a compreensão do estado fiscal contemporâneo. Coimbra: Almedina, 2009, p. 110-111.

${ }^{45}$ NABAIS, José Casalta. 0 dever fundamental de pagar impostos: contributo para a compreensão do estado fiscal contemporâneo. Coimbra: Almedina, 2009, p. 102.

${ }^{46}$ MEDEIROS, Fernanda Luiza Fontoura de. Direito dos Animais. Porto Alegre: Livraria do Advogado, 2013, p. 97.

${ }^{47}$ NABAIS, José Casalta. O dever fundamental de pagar impostos: contributo para a compreensão do estado fiscal contemporâneo. Coimbra: Almedina, 2009, p. 102.
} 
ISSN 1981-3694

(DOI): $10.5902 / 1981369438399$

A terceira categoria é a dos deveres fundamentais de conteúdo econômico, social ou cultural, (grifo nosso) frutos da noção de Estado Social, porquanto tutelam essencialmente valores sociais importantes que a ordem constitucional privilegia. São os deveres relativos à saúde coletiva, ao ambiente, ao patrimônio cultural. Essa categoria de deveres fundamentais tem como beneficiária a coletividade em geral, extravasando a órbita comunitária nacional e perspectivando-se para a humanidade como um todo. Ademais, Nabais reconhece que nessa categoria de deveres, notadamente por razões de cunho ecológico, também são beneficiários as futuras gerações e o mundo não-humano (animais, plantas etc.). ${ }^{48}$

Destaque-se que os deveres fundamentais, por estarem a serviço de valores comunitários que a comunidade estatal reconhece como seus, impõem, como contrapartida, ao Estado, titular ativo número um dos deveres fundamentais, determinadas posições jurídicopassivas, seja organizando e estruturando o funcionamento de serviços especializados necessários para o cumprimento de determinados deveres pelos seus destinatários (por exemplo, serviços tributários para viabilizar o dever fundamental de pagar impostos), seja assegurando condições para o cumprimento dos deveres fundamentais, como exigem, sobretudo, os deveres de conteúdo econômico, social ou cultural. ${ }^{49}$

No tocante aos destinatários (ou titulares passivos) dos deveres fundamentais, a resposta é obtida a partir da análise das suas características. Como já mencionado, os deveres fundamentais são posições jurídicas essencialmente individuais. De ressaltar, porém, que não apenas as pessoas físicas, mas também as pessoas jurídicas de direito público e direito privado, ou ainda organizações coletivas sem personalidade jurídica, são destinatárias dos deveres fundamentais que sejam compatíveis com sua natureza. ${ }^{50}$

Cabe salientar que, na perspectiva defendida por Nabais ${ }^{51}$, os deveres fundamentais não são diretamente aplicáveis aos seus destinatários subjetivos, já que, em regra, eles não têm conteúdo e sanção concretizados na constituição, exigindo, pois, regulamentação infraconstitucional, razão pela qual pode-se considerar que o legislador ordinário é o destinatário principal de todos os deveres fundamentais. Assinale-se aqui que a referida tese de

\footnotetext{
${ }^{48}$ NABAIS, José Casalta. 0 dever fundamental de pagar impostos: contributo para a compreensão do estado fiscal contemporâneo. Coimbra: Almedina, 2009, p. 53-54.

49 MIRANDA, Jorge. Manual de Direito Constitucional, Tomo IV - Direitos Fundamentais, 3. ed. Coimbra: Almedina, 2000, p. 165.

50 NABAIS, José Casalta. 0 dever fundamental de pagar impostos: contributo para a compreensão do estado fiscal contemporâneo. Coimbra: Almedina, 2009, p. 110.

51 NABAIS, José Casalta. A face oculta dos direitos fundamentais: os deveres e os custos dos direitos. Revista da AGU, Brasília, v.1, 2001, p. 81.
} 
ISSN 1981-3694

(DOI): $10.5902 / 1981369438399$

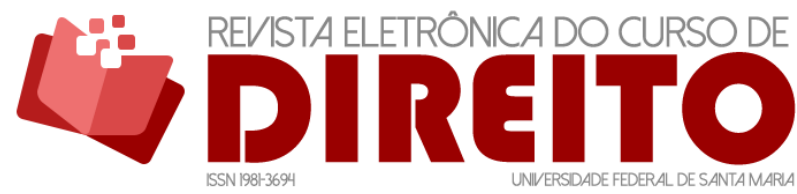

O REGIME JURÍDICO-CONSTITUCIONAL DOS DEVERES

FUNDAMENTAIS

Nabais acerca da aplicabilidade mediata dos deveres fundamentais será adiante melhor analisada.

\section{A TIPOLOGIA DOS DEVERES FUNDAMENTAIS}

Os deveres fundamentais podem ser objeto de diversas classificações. Adota-se, como base, naquilo que interessa ao presente trabalho, o modelo classificatório desenvolvido por Nabais, dado sua completude e aprofundamento teórico, com os acréscimos pontuais decorrentes das contribuições de outros autores.

Com efeito, a primeira classificação tipológica diz respeito à autonomia do conteúdo interno dos deveres fundamentais. Por esse prisma, eles podem ser: (a) deveres fundamentais autônomos em sentido estrito; e (b) deveres fundamentais conexos ou associados à direitos fundamentais, grifo nosso. Importante salientar que ambos integram a categoria dos deveres fundamentais que é uma categoria jurídico-constitucional autônoma, contudo, os primeiros possuem conteúdo interno totalmente desvinculado de qualquer direito fundamental. Por isso autônomos em sentido estrito, enquanto os segundos possuem conteúdo interno não autônomo já que vinculado ao conteúdo de um direito fundamental, por isso associado ou conexo a ele. Nabais $^{52}$ deixa claro que a não autonomia dos deveres conexos ou associados a direitos fundamentais é apenas do ponto de vista de seu conteúdo interno, sendo eles chamados de "direitos-deveres" ou "deveres-direitos", consoante sejam deveres acessórios ou principais com relação aos direitos a que se ligam.

Em semelhante sentido, Vieira de $A_{\text {ndrade }}^{53}$ afirma que os deveres fundamentais autônomos em sentido estrito detêm essa característica justamente por serem impostos pela constituição "independentemente de qualquer direito". Bons exemplos são os do dever fundamental de pagar impostos ou ainda do dever fundamental de defesa da pátria. Por outro lado, os deveres associados ou conexos a direitos fundamentais, podem alterar tanto o conteúdo estrutural dos direitos a que se ligam, quanto a natureza destes, os quais passam a ser compreendidos como verdadeiros "direitos de solidariedade", "direitos circulares" ou "direitos-

\footnotetext{
52 NABAIS, José Casalta. 0 dever fundamental de pagar impostos: contributo para a compreensão do estado fiscal contemporâneo. Coimbra: Almedina, 2009, p. 114.

53 VIEIRA DE ANDRADE, José Carlos. Os direitos fundamentais na Constituição Portuguesa de 1976. 5. ed. Coimbra: Almedina, 2012, p. 151-152.
} 
ISSN 1981-3694

(DOI): $10.5902 / 1981369438399$

deveres". ${ }^{54}$ Essa conexão de conteúdo não significa, ressalte-se, identidade de conteúdo. Logo, os deveres fundamentais associados ou conexos a direitos fundamentais não excluem a liberdade de exercício do direito associado ou conexo, porquanto ambos se dirigem a realidades jurídicas diferentes, embora com um objetivo comum.

$\mathrm{Na}$ doutrina nacional, Sarlet reafirma essa classificação ao referir que a diferença reside no fato de que os deveres fundamentais autônomos não se relacionam diretamente com nenhum direito subjetivo, diferentemente do que ocorre com os deveres fundamentais conexos ou associados a direitos fundamentais. 0 exemplo dado por Sarlet ${ }^{55}$, a partir da Constituição brasileira, ilustra bem o exposto acima:

Os direitos fundamentais a um ambiente equilibrado e à saúde, por exemplo, constituem típicos direitos-deveres, pois os deveres fundamentais de proteção do ambiente e de promoção da saúde encontram-se vinculados de forma direta ao comando normativo-constitucional que prevê os direitos fundamentais em questão, conforme é possível depreender do conteúdo do disposto no art. 225, caput, bem como no art. 196, ambos da CF, cuidando-se, portanto, de típicos deveres do tipo conexo [...]. O direito fundamental ao ambiente, portanto, como também tem sustentado abalizada doutrina, atua simultaneamente como 'direito' e 'dever' fundamental, o que, de resto, decorre do próprio conteúdo normativo do art. 225 da CF, especialmente em relação ao texto do caput, que dispõe de forma expressa sobre o dever da coletividade 'de defender e preservar o ambiente' para as presentes e futuras gerações. [...]

A segunda classificação tipológica diz com a natureza do conteúdo dos deveres fundamentais. Nesse particular, os deveres fundamentais podem ser classificados em (a) deveres fundamentais positivos e (b) deveres fundamentais negativos. Os primeiros (positivos) implicam ao destinatário do dever uma obrigação consubstanciada em um comportamento positivo, ou seja, um facere, consistente em prestações pessoais ou materiais. Medeiros ${ }^{56}$ cita o dever de prestar o serviço militar e o dever de votar como típicos deveres fundamentais de prestações pessoais (de fazer), os quais, aliás, correspondem à grande maioria dos deveres fundamentais. Já os deveres fundamentais de prestações materiais, tem no dever fundamental de pagar impostos um bom exemplo. Por outro lado, os deveres fundamentais negativos implicam aos destinatários obrigações consistentes em um comportamento negativo, uma abstenção, um non

\footnotetext{
54 VIEIRA DE ANDRADE, José Carlos. Os direitos fundamentais na Constituição Portuguesa de 1976. 5. ed. Coimbra: Almedina, 2012, p. 158.

55 SARLET, Ingo Wolfgang. A eficácia dos direitos fundamentais: uma teoria geral dos direitos fundamentais na perspectiva constitucional. 10. ed. Porto Alegre: Livraria do Advogado Editora, 2010, p. 228.

${ }^{56}$ MEDEIROS, Fernanda Luiza Fontoura de. Meio ambiente: direito e dever fundamental. Porto Alegre: Livraria do Advogado, 2004, p. 127.
} 
ISSN 1981-3694

(DOI): $10.5902 / 1981369438399$

facere, os quais, como salienta Nabais $^{57}$, não se confundem com os deveres correlativos de direitos fundamentais. Importante salientar que essa classificação esbarra naqueles deveres fundamentais de maior complexidade, que não se enquadram apenas em uma dessas categorias, porquanto simultaneamente positivos e negativos, como, por exemplo, é o dever fundamental de proteção do ambiente (grifo nosso).

Ainda, considerando serem raras as hipóteses de deveres fundamentais expressamente previstos no texto constitucional, ao contrário do que ocorre com os direitos fundamentais, é de ser feita a diferenciação entre: (a) deveres fundamentais expressos e (b) deveres fundamentais implícitos, mesmo que não haja consenso acerca de quais sejam esses deveres fundamentais implícitos $^{58}$, grifo nosso. Essa classificação é defendida por Nabais, para quem os deveres fundamentais obedecem ao princípio da tipicidade. Em outras palavras: no plano infraconstitucional, o legislador ordinário pode estabelecer deveres, mesmo dotados de materialidade fundamental. Contudo, sem assento constitucional expresso ou implícito, serão meros deveres legais. Aliás, como já salientado, na perspectiva teórica de Nabais nem mesmo uma suposta cláusula de deverosidade social poderia dar suporte a uma abertura material a deveres fundamentais. ${ }^{59}$ Esse tema será, porém, adiante melhor analisado.

Por fim, cabe destacar a classificação tipológica que diferencia os deveres fundamentais do ponto de vista da natureza do vínculo obrigacional que conforma o dever em questão. Nessa classificação os deveres fundamentais dividem-se em: (a) deveres que vinculam os indivíduos nas suas relações com o Estado, ou seja, os deveres cívico-políticos, tal como o dever de defesa da pátria e o dever de voto; (b) deveres que criam obrigações aos indivíduos para com a coletividade em geral, ou seja, os deveres econômicos, sociais, culturais, os quais tutelam determinados valores sociais que pela sua relevância foram privilegiados pela ordem constitucional, tal como ocorre com os deveres de trabalhar, de cultivar a terra, de proteger e preservar o meio ambiente e o patrimônio cultural, de defender e promover a saúde; (c) deveres para com outras pessoas, como ocorre tipicamente com o dever dos pais de manutenção e

\footnotetext{
57 NABAIS, José Casalta. 0 dever fundamental de pagar impostos: contributo para a compreensão do estado fiscal contemporâneo. Coimbra: Almedina, 2009, p. 112.

58 SARLET, Ingo Wolfgang. A eficácia dos direitos fundamentais: uma teoria geral dos direitos fundamentais na perspectiva constitucional. 10. ed. Porto Alegre: Livraria do Advogado Editora, 2010, p. 229.

59 NABAIS, José Casalta. O dever fundamental de pagar impostos: contributo para a compreensão do estado fiscal contemporâneo. Coimbra: Almedina, 2009, p. 62-63.
} 
ISSN 1981-3694

(DOI): $10.5902 / 1981369438399$

L U DIREITO

O REGIME JURÍDICO-CONSTITUCIONAL DOS DEVERES

FUNDAMENTAIS

educação dos filhos; (d) deveres para consigo próprio, como ocorre com o dever de preservar a própria saúde ${ }^{60}$, grifo nosso.

\section{DEVERES FUNDAMENTAIS E PRINCÍPIOS CONSTITUCIONAIS ESTRUTURANTES}

Há muitos anos os teóricos do direito discutem o papel normativo que é exercido pelos princípios jurídicos, diferenciando-os das regras jurídicas. A distinção entre essas duas espécies de normas jurídicas adquiriu especial importância em teoria do direito, notadamente a partir das contribuições teóricas de Dworkin e Alexy. ${ }^{61}$

São diversos os critérios utilizados para distinguir princípios e regras, alguns dos quais, inclusive, inconciliáveis entre si. Souza ${ }^{62}$ destaca a ausência de consenso doutrinário em alguns aspectos importantes, tais como: (a) se os princípios e as regras seriam dois gêneros autônomos de categorias normativas (relação de cogeneralidade); (b) se os princípios e as regras seriam duas espécies da mesma categoria normativa designada genericamente, como "norma jurídica" (relação de especialidade); ou (c) se entre os princípios e as regras há uma relação que diz respeito apenas a dois modos distintos de aplicação de enunciados normativos a casos concretos. Como bem observa o autor, muito embora existam divergências consideráveis dentro de cada uma dessas hipóteses, notadamente com relação aos critérios adotados para distinção conceitual, a doutrina tem convergido no entendimento de que a distinção entre princípios e regras é uma distinção entre diferentes tipos normativos. Isso, embora abrande, não reduz as controvérsias entre os juristas, porquanto tal distinção também depende de critérios distintivos sobre os quais há divergência conceitual.

O fato é que a técnica dos princípios é amplamente utilizada pelo direito moderno, em todos os seus ramos. Não é objetivo do presente trabalho discorrer sobre a posição ou autoridade dos princípios na ordem jurídico-constitucional brasileira, tampouco adentrar no cerne das controvérsias ainda em voga sobre os melhores critérios para diferenciar princípios de outras categorias normativas, como as regras jurídicas e os postulados normativos. Essa última,

\footnotetext{
${ }^{60}$ NABAIS, José Casalta. 0 dever fundamental de pagar impostos: contributo para a compreensão do estado fiscal contemporâneo. Coimbra: Almedina, 2009, p. 114-115.

${ }^{61}$ DWORKIN, Ronald. Levando os direitos a sério. Trad. Nelson Boeira. 3. ed. - São Paulo: Martins Fontes, 2010; ALEXY, Robert. Teoria dos Direitos Fundamentais. Trad. de Virgílio Afonso da Silva. São Paulo: Malheiros, 2008.

62 SOUZA, Felipe Oliveira de. 0 raciocínio jurídico entre princípios e regras. In: Brasília, a. 48, n. 192, 2011, p. 95-109.
} 
ISSN 1981-3694

(DOI): $10.5902 / 1981369438399$

aliás, preconizada na doutrina pátria por Humberto Ávila ${ }^{63}$. Para os fins aqui propostos, basta dizer, com apoio em Canotilho ${ }^{64}$, que os princípios "são normas jurídicas impositivas de uma optimização, compatíveis com vários graus de concretização, consoante os condicionalismos fácticos e jurídicos." Ou seja, permitem o balanceamento de valores e interesses conforme seu peso, bem como a ponderação de outros princípios que eventualmente estejam em conflito.

No que se refere à relação entre os princípios constitucionais e os deveres fundamentais, alguns aspectos merecem ser destacados. Não são apenas os direitos fundamentais que fornecem suporte para uma adequada compreensão do quadro normativo dos deveres fundamentais, mas também os princípios constitucionais exercem essa função. Outro aspecto importante da relação entre deveres fundamentais e os princípios constitucionais é o condicionamento recíproco entre ambas as figuras constitucionais. ${ }^{65}$ Como bem observa Basso ${ }^{66}$, isso significa que:

[...] de um lado, os deveres são condicionados pelos princípios (como ocorre por exemplo nos casos de aplicação do princípio da proporcionalidade, ou no reconhecimento de limites decorrentes da dignidade da pessoa humana); e de outro, que esses princípios é que são limitados por deveres fundamentais (como ocorre, por exemplo, na limitação do princípio da igualdade, quando do dever fundamental de prestar serviço militar são excepcionados as mulheres e aqueles que aleguem imperativo de consciência). Assim, conclui-se que a relação entre deveres fundamentais e princípios constitucionais é muito próxima (senão idêntica) da relação entre estes e os direitos fundamentais.

Os deveres fundamentais têm como fundamento lógico o princípio da dignidade da pessoa humana. Nos dizeres de $\mathrm{Nabais}^{67}$, os deveres fundamentais são "expressão da soberania assente na dignidade da pessoa humana." Já o fundamento jurídico dos deveres fundamentais é a Constituição, pois como já ressaltado, os deveres fundamentais necessitam ser identificados expressa ou implicitamente na Constituição.

Dentre os princípios que integram o regime jurídico-constitucional dos deveres fundamentais, expressos ou implicitamente positivados no texto constitucional brasileiro,

\footnotetext{
${ }^{63}$ ÁVILA, Humberto. Teoria dos Princípios: da definição à aplicação dos princípios jurídicos. 6. ed. São Paulo: Malheiros, 2006.

${ }^{64}$ CANOTILHO, José Joaquim Gomes. Direito Constitucional e Teoria da Constituição. 7. ed. Coimbra: Almedina, 2003, p. 1034-1035.

${ }^{65}$ NABAIS, José Casalta. 0 dever fundamental de pagar impostos: contributo para a compreensão do estado fiscal contemporâneo. Coimbra: Almedina, 2009, p. 127-129.

${ }^{66}$ BASSO, Joaquim. Notas sobre o regime jurídico dos deveres fundamentais no ordenamento jurídico brasileiro. Revista Direito UFMS, v. 1, n. 2, Campo Grande, MS, 2016, p. 102-103.

${ }^{67}$ NABAIS, José Casalta. A face oculta dos direitos fundamentais: os deveres e os custos dos direitos. Revista da AGU, Brasília, v.1, 2001, p. 77.
} 
ISSN 1981-3694

(DOI): $10.5902 / 1981369438399$

merecem destaque os princípios da igualdade, da proporcionalidade, da subsidiariedade e da solidariedade.

O primeiro a ser aqui destacado é o princípio da igualdade, clássico princípio do Estado de Direito, que em nosso sistema constitucional tem previsão expressa tanto no preâmbulo quanto no caput do art. $5^{\circ}$ da Constituição da República. No que se refere aos deveres fundamentais, o princípio da igualdade, assegura o tratamento igual do que seja essencialmente igual e o tratamento desigual do que seja desigual na sua essência. Com efeito, aplicado à matéria dos deveres fundamentais, o princípio da igualdade implica o reconhecimento de que a imposição de deveres não poderá se consubstanciar na imposição de encargos arbitrários, mas também significa dizer que a titularidade de deveres fundamentais não necessariamente deverá ser objeto de repartição igualitária. ${ }^{68}$ Portanto, é muito importante observar os possíveis sentidos de compreensão que o princípio da igualdade assume no âmbito dos deveres fundamentais: (a) o sentido de proibição de arbítrio no plano legislativo para o estabelecimento de diferenciações que não se amparem em critérios objetivos e constitucionalmente relevantes; (b) o sentido de proibição de discriminações arbitrárias de caráter subjetivo, como sexo, raça, religião, ideologia política etc.; (c) o sentido de exigência de igual tratamento nos domínios em que a Constituição consagre direitos subjetivos à igualdade, como nos casos dos cônjuges, dos filhos, do sufrágio etc.; (d) o sentido de imposição de discriminações positivas para compensar desigualdades fáticas. ${ }^{69}$

Em outras palavras, pode-se afirmar que, em essência, o princípio da igualdade aplicado aos deveres fundamentais implica uma vedação de que se estabeleçam quaisquer diferenciações de tratamento sem justificação racional, critérios objetivos. Do ponto de vista jurídicoconstitucional, recaindo os deveres sobre todos os indivíduos em igual peso e proporção, salvo quando a constituição prescrever diretamente ou autorizar uma diferenciação de tratamento

\footnotetext{
${ }^{68}$ Carla Amado Gomes exemplifica: "No caso do dever de protecção do ambiente, já vimos que este assume conteúdos muito díspares consoante as características do destinatário, nomeadamente conforme as actividades desenvolvidas por este. A diferenciação é notória relativamente a todos aqueles que se dediquem à exploração de actividades com alto potencial lesivo dos bens ambientais. 0 agravamento da intensidade do dever de proteger o ambiente nessas situações, com a acumulação de obrigações positivas e negativas na esfera jurídica do empresário, é plenamente compreensível e justificável à luz de factores objectivos." GOMES, Carla Amado. Risco e modificação do acto autorizativo concretizador de deveres de protecção do ambiente. Tese de Doutorado em Ciências Jurídico-Políticas, Faculdade de Direito. Universidade de Lisboa, Lisboa, 2007, p. 132.

69 NABAIS, José Casalta. 0 dever fundamental de pagar impostos: contributo para a compreensão do estado fiscal contemporâneo. Coimbra: Almedina, 2009, p. 140-143. Ressalte-se que o quarto sentido dado ao princípio da igualdade no âmbito dos deveres fundamentais é criticado por Nabais por entender ter mais relação com o princípio do estado social.
} 
ISSN 1981-3694

(DOI): $10.5902 / 1981369438399$

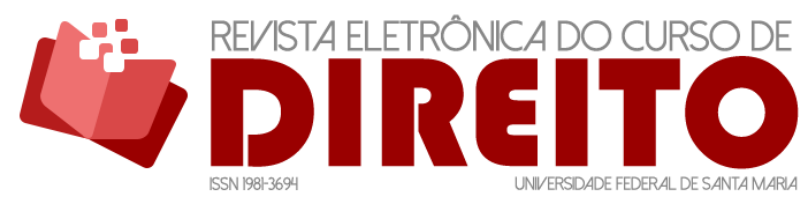

O REGIME JURÍDICO-CONSTITUCIONAL DOS DEVERES

FUNDAMENTAIS

pelo legislador ordinário. Daí porque Nabais $^{70}$ os define como "deveres de igualdade - deveres de suportar tais encargos na proporção dos benefícios comunitários usufruíveis, e não deveres de igualização, grifo nosso."

Outro princípio que integra o regime jurídico dos deveres fundamentais é o princípio da proporcionalidade. $\mathrm{Na}$ medida em que os deveres fundamentais podem justificar, em prol do interesse comunitário, possíveis limitações na esfera subjetiva dos direitos fundamentais, a proporcionalidade ganha relevo. Para o fim de assegurar que as medidas que venham a ser tomadas em nome dos deveres fundamentais e que porventura venham a limitar ou redefinir o conteúdo de direitos fundamentais, "estejam ajustadas ao sistema constitucional, resguardando, além disso, sempre o núcleo essencial do direito fundamental afetado". ${ }^{71}$

No Brasil, o princípio da proporcionalidade não está expresso no texto constitucional, porém, segundo Barroso ${ }^{72}$, seu fundamento vincula-se aos postulados do devido processo legal substantivo e de justiça, tratando-se de um valioso instrumento de proteção dos direitos fundamentais e do interesse público, já que permite o controle da discricionariedade dos atos do Poder Público e serve para delimitar a medida com que certa norma deva ser interpretada em um caso específico para que ocorra a melhor realização do(s) fim(ns) constitucional(ais) pretendido(s). Por conseguinte, pode-se afirmar que os deveres fundamentais devem observar o princípio da proporcionalidade lato sensu, também chamado de princípio da proibição do excesso $^{73}$, nos diferentes aspectos ou subprincípios em que ele se desdobra: adequação, necessidade e proporcionalidade em sentido estrito. Por adequação, compreende-se a adequação entre o fim perseguido e o instrumento empregado. Em outras palavras, trata-se de controlar a relação de adequação entre a medida adotada e o fim público subjacente. ${ }^{74}$ Por necessidade (exigibilidade ou menor ingerência possível), objetiva-se que a medida seja exigível ou necessária, não havendo meio menos gravoso para se chegar ao mesmo resultado. Coloca-se em cena, portanto, a ideia de que o cidadão tem direito a menor desvantagem possível, exigindo

\footnotetext{
${ }^{70}$ NABAIS, José Casalta. 0 dever fundamental de pagar impostos: contributo para a compreensão do estado fiscal contemporâneo. Coimbra: Almedina, 2009, p. 145.

71 SARLET, Ingo Wolfgang. A eficácia dos direitos fundamentais: uma teoria geral dos direitos fundamentais na perspectiva constitucional. 10. ed. Porto Alegre: Livraria do Advogado Editora, 2010, p. 231.

72 BARROSO, Luís Roberto. Interpretação constitucional como interpretação específica. In: CANOTILHO, J. J. Gomes; MENDES, Gilmar F.; SARLET, Ingo W.; STRECK, Lenio L. (Coords.). Comentários à Constituição do Brasil. São Paulo: Saraiva/Almedina, 2013, p. 91-96.

73 PIEROTH, Bodo; SCHLINK, Bernhard. Direitos Fundamentais. Trad. António Francisco de Sousa e António Franco. São Paulo: Saraiva, 2012, p. 138.

${ }^{74}$ CANOTILHO, José Joaquim Gomes. Direito Constitucional e Teoria da Constituição. 7. ed. Coimbra: Almedina, 2003, p. 269.
} 
ISSN 1981-3694

(DOI): $10.5902 / 1981369438399$

sempre a prova de que não era possível adotar outro meio menos oneroso para o cidadão. Já na proporcionalidade em sentido estrito, entendida como princípio da justa medida, exige-se a demonstração de que, numa análise de custo benefício, o que se perde com a medida (custos) não supera o que se ganha com ela (benefícios). Nesse sentido, "meios e fins são colocados em equação mediante um juízo de ponderação, com o objetivo de se avaliar se o meio utilizado é ou não desproporcional em relação ao fim". ${ }^{75}$

Cabe destacar, com apoio em Nabais, que os dois primeiros aspectos ou subprincípios da proporcionalidade se dirigem ao legislador constituinte, porquanto é ele quem tem a tarefa de, ao decidir pela consagração constitucional de deveres fundamentais, realizar o juízo da sua indispensabilidade e da sua aptidão. Já o terceiro aspecto (proporcionalidade em sentido estrito ou justa medida), volta-se mais ao legislador ordinário, na sua tarefa de concretização legal dos deveres. No que se refere ao sancionamento para a hipótese de não cumprimento dos deveres fundamentais, tarefa que, em regra, também se destina ao legislador ordinário, novamente os diferentes aspectos da proporcionalidade devem ser considerados pelo legislador, "[...] decidindo se deve sancionar ou não, por que via (via penal ou outra via sancionatória) e em que medida". ${ }^{76}$

Também integra o regime jurídico geral dos deveres fundamentais o princípio da subsidiariedade, grifo nosso. Esse princípio, aliás, é muito pouco explorado na doutrina jurídica constitucional contemporânea, mesmo possuindo uma importância extrema, sobretudo no que se refere à relação entre Estado e sociedade e sobre o papel dos indivíduos na observância, cumprimento e respeito aos valores comunitários reconhecidos pela ordem constitucional vigente. Diz respeito também à participação dos indivíduos nas tarefas comunitárias básicas e no próprio sistema democrático.

A subsidiariedade se consubstancia em uma ideia antiquíssima, cujas primeiras referências se localizam no pensamento de Aristóteles e que posteriormente foi retomada pela Doutrina Social da Igreja Católica, com grande desenvolvimento, notadamente por São Tomás de Aquino. Posteriormente a noção de subsidiariedade está presente nas obras de autores como Althusius, Stuart Mill, Kant, Proudhon, Tocqueville, Rousseau, Ketteler e Jellinek. ${ }^{77}$

\footnotetext{
${ }^{75}$ CANOTILHO, José Joaquim Gomes. Direito Constitucional e Teoria da Constituição. 7. ed. Coimbra: Almedina, 2003, p. 270.

${ }^{76}$ NABAIS, José Casalta. 0 dever fundamental de pagar impostos: contributo para a compreensão do estado fiscal contemporâneo. Coimbra: Almedina, 2009, p. 146.

77 VILHENA, Maria do Rosário. 0 princípio da subsidiariedade no direito comunitário. Coimbra: Almedina, 2002, p. 25.
} 
ISSN 1981-3694

(DOI): $10.5902 / 1981369438399$

0 princípio da subsidiariedade tem várias aplicações. Como bem observa Moreira Neto $^{78}$, trata-se de um princípio que regula as relações de poder e de finalidade nas relações sociais, escalonando atribuições de acordo com os interesses sociais a serem atendidos, promovendo uma repartição de competências entre Estado e sociedade, redefinindo os níveis de atuação individual, coletiva e do próprio Estado na concretização dos valores comunitários. 0 princípio da subsidiariedade também pode ser utilizado para fins de redefinição de competências entre os entes federativos ou mesmo sobre a atuação do Estado na ordem econômica. No que se refere à ordem constitucional brasileira, a subsidiariedade é considerada um princípio de ordem social, que exige, "[...] uma sociedade que, a par de pluralista, seja organizada, forte, autônoma, livre e aberta". ${ }^{79} \mathrm{O}$ fundamento ético basilar da subsidiariedade reside na maior autonomia aos seres humanos, tornando-se um instrumento político de integração e participação social. Não se trata, portanto, de uma autonomia descompromissada do contexto comunitário, mas, ao contrário, uma autonomia interdependente, participativa, vinculada à realização do interesse público. ${ }^{80}$

A subsidiariedade, como fundamento de deveres fundamentais, não significa necessariamente reduzir o papel do Estado a um caráter acessório ou secundário, notadamente no que se refere aos deveres de proteção a direitos fundamentais sociais. A esse respeito, calha a lição de Canotilho, quando afirma que o princípio da subsidiariedade muito embora tenha sido utilizado, originalmente, no plano político, para justificar o papel meramente acessório do Estado na conformação da vida econômica e social. Síntese do capitalismo liberal e do neoliberalismo contemporâneo, modernamente tem sido reinterpretado por um viés diferente, muito próximo da ideia de autorresponsabilidade. ${ }^{81}$ Isso porque mesmo o modelo de Estado Social não responde como um garantidor universal dos direitos fundamentais, e, portanto, cada integrante do corpo social deve realizar sua cota-parte por meio de deveres que "transcendem um mero dever de respeito mútuo entre os indivíduos de determinado grupo social, mas alcançam deveres de cunho positivo, especialmente quando esteja em questão a dignidade da pessoa humana". ${ }^{82}$

\footnotetext{
${ }^{78}$ MOREIA NETO, Diogo de Figueiredo. Mutações do direito administrativo. Rio de Janeiro: Renovar, 2000, p. 20.

79 TORRES, Sílvia Faber. O princípio da subsidiariedade no direito público contemporâneo. Rio de Janeiro: Renovar, 2001, p. 124.

${ }^{80}$ GABARDO, Emerson. Interesse público e subsidiariedade. Belo Horizonte: Fórum, 2009, p. 316.

${ }^{81}$ CANOTILHO, José Joaquim Gomes. Direito Constitucional e Teoria da Constituição. 7. ed. Coimbra: Almedina, 2003, p. 342.

82 SARLET, Ingo Wolfgang; FENSTERSEIFER, Tiago.Direito constitucional ambiental: constituição, direitos fundamentais e proteção do ambiente. 3. ed. São Paulo: Revista dos Tribunais, 2013, p. 231.
} 
ISSN 1981-3694

(DOI): $10.5902 / 1981369438399$

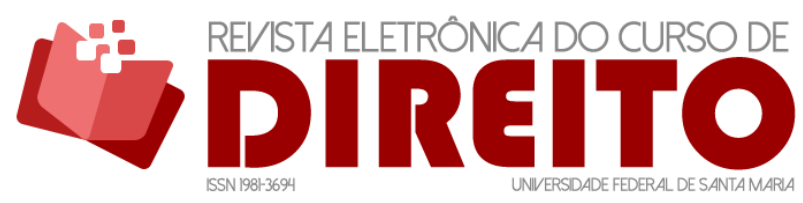

O REGIME JURÍDICO-CONSTITUCIONAL DOS DEVERES

FUNDAMENTAIS

Outro princípio que integra o regime jurídico geral dos deveres fundamentais, e tem, ressalte-se, importância ímpar para o dever fundamental ecológico, é o princípio da solidariedade (grifo nosso), o qual, como assinalado por Fensterseifer ${ }^{83}$, "[...] renasce como Fênix das cinzas jurídicas da Revolução Francesa, para transformar-se no novo marco jurídicoconstitucional contemporâneo".

Cabe destacar que a ideia de solidariedade, em termos normativos, não é só concebida como uma virtude moral, mas como um princípio de justiça. A esse respeito, Ricardo Lobo Torres $^{84}$, observa que a ideia de solidariedade guarda íntima proximidade com a ideia de justiça, porquanto ambas projetam e fortalecem a perspectiva de um "vínculo de apoio mútuo entre os grupos que participam dos grupos beneficiários da redistribuição dos bens sociais." Aliás, essa proximidade foi levada a efeito pelo legislador constituinte de 1988 , na medida em que ao princípio da solidariedade foi destinado tratamento de objetivo fundamental da República Federativa do Brasil, conforme disposto no art. $3^{\circ}$, I, da CF/88, que prevê "a construção de uma sociedade livre, justa e solidária", ao lado dos demais objetivos fundamentais de garantia do "desenvolvimento nacional" (art. $3^{\circ}$, II), da "erradicação da pobreza e da marginalização social e a redução das desigualdades sociais e regionais" (art. $3^{\circ}$, III), e da promoção do "bem de todos, sem preconceitos de origem, raça, sexo, cor, idade e quaisquer outras formas de discriminação" (art. $3^{\circ}$, IV). A solidariedade, ao lado da justiça, consolida-se, portanto, como objetivo fundamental da ordem jurídica brasileira, como importante instrumento hermenêutico ${ }^{85}$ e fundamento normativo dos deveres fundamentais no Brasil. Nesse sentido, colaciona-se recente julgado do egrégio Supremo Tribunal Federal:

Ação direta de inconstitucionalidade. Julgamento conjunto das ADI $n^{\circ} 2.390$, 2.386, 2.397 e 2.859. Normas federais relativas ao sigilo das operações de instituições financeiras. [...] Confluência entre os deveres do contribuinte (o dever fundamental de pagar tributos) e os deveres do Fisco (o dever de bem tributar e fiscalizar). [...] ADI $n^{\circ}$ 2.859. Ação que se conhece em parte e, na parte conhecida, é julgada improcedente. $A D I n^{\circ} 2.390,2.386,2.397$. Ações conhecidas e julgadas improcedentes. [...] 5. A ordem constitucional instaurada em 1988 estabeleceu, dentre os objetivos da República Federativa do Brasil, a construção de uma sociedade livre, justa e solidária, a erradicação da pobreza e a marginalização e a redução das desigualdades sociais e regionais. Para tanto, a Carta foi generosa na previsão de direitos individuais, sociais, econômicos e culturais para o cidadão. Ocorre que, correlatos a esses direitos, existem também deveres, cujo atendimento é, também, condição sine qua non para a

${ }^{83}$ FENSTERSEIFER, Tiago. Direitos fundamentais e proteção do ambiente: a dimensão ecológica da dignidade humana no marco jurídico-constitucional do Estado Socioambiental de Direito. Porto Alegre: Livraria do Advogado, 2008, p. 111.

${ }^{84}$ TORRES, Ricardo Lobo. Tratado de direito constitucional, financeiro e tributário: valores e princípios constitucionais tributários. Rio de Janeiro: Renovar, v. II, 2005, p. 183.

${ }^{85}$ BELCHIOR, Germana P. Neiva. Hermenêutica jurídica ambiental. São Paulo: Saraiva, 2011, p. 131. 
ISSN 1981-3694

(DOI): $10.5902 / 1981369438399$

realização do projeto de sociedade esculpido na Carta Federal. [...]. (ADI 2859, Relator: Min. DIAS TOFFOLI, Tribunal Pleno, julgado em 24/02/2016, ACÓRDÃO ELETRÔNICO DJe-225 DIVULG 20-10-2016 PUBLIC 21-10-2016) (Grifo do autor)

O princípio da solidariedade, em matéria de deveres fundamentais, torna exigível do indivíduo uma cidadania responsável e um comprometimento com a realização do bem-estar coletivo. Assim, em essência, como afirma Gomes ${ }^{86}$, "estar investido em deveres não é um status subjectionis, mas antes um reflexo da responsabilidade social que grava cada indivíduo - ou seja, é também um status activus." Dito de outro modo, de acordo com as expressões historicamente cunhadas por Jellinek, ter deveres fundamentais não significa sujeição em face do Estado. Significa sim, ser ativamente responsável, solidário e comprometido com a vida em sociedade e com a realização de objetivos de interesse comum.

A solidariedade expressa a necessidade de uma coexistência harmônica e responsável dos indivíduos em um corpo social "para além de uma obrigação ou dever meramente moral", devendo ser encarada como princípio normativo estruturante dos deveres fundamentais, tratando-se, portanto, de "[...] pilar fundamental à construção de uma sociedade e de um Estado de Direito guardiões dos direitos fundamentais de todos os seus integrantes, sem exclusões". ${ }^{87}$ Com efeito, a figura do dever fundamental, na ordem jurídico-constitucional brasileira, se assenta na ideia de solidariedade responsável dos indivíduos para com a comunidade estatal em que se inserem. Em matéria ambiental, aliás, tal perspectiva é ampliada para além das fronteiras geopolíticas estatais, bem como para além das relações entre os seres humanos. Com tal premissa, Gomes ${ }^{88}$ destaca que com a tomada de consciência e de novas percepções da realidade que cercam as questões sociais, ambientais, econômicas e culturais, introduz-se "[...] um novo patamar de solidariedade, que remete o Estado para um plano organizacional e faz avultar o papel de cada indivíduo no contexto de sua vivência comunitária". São essas novas percepções, lastreadas na solidariedade, que impulsionam o legislador constituinte na formulação dos deveres fundamentais.

\footnotetext{
86 GOMES, Carla Amado. Risco e modificação do acto autorizativo concretizador de deveres de protecção do ambiente. Tese de Doutorado em Ciências Jurídico-Políticas, Faculdade de Direito. Universidade de Lisboa, Lisboa, 2007, p. 93.

87 FENSTERSEIFER, Tiago. Direitos fundamentais e proteção do ambiente: a dimensão ecológica da dignidade humana no marco jurídico-constitucional do Estado Socioambiental de Direito. Porto Alegre: Livraria do Advogado, 2008, p. 114.

88 GOMES, Carla Amado. Risco e modificação do acto autorizativo concretizador de deveres de protecção do ambiente. Tese de Doutorado em Ciências Jurídico-Políticas, Faculdade de Direito. Universidade de Lisboa, Lisboa, 2007, p. 102.
} 
ISSN 1981-3694

(DOI): $10.5902 / 1981369438399$

L U DIREITO

O REGIME JURÍDICO-CONSTITUCIONAL DOS DEVERES

FUNDAMENTAIS

\section{ABERTURA MATERIAL E APLICABILIDADE DOS DEVERES FUNDAMENTAIS}

Como já demonstrado anteriormente, a tipicidade constitucional (expressa ou implícita) é uma característica dos deveres fundamentais. Em razão disso, a posição majoritária da doutrina, capitaneada por Nabais, é claramente contrária à abertura material a deveres fundamentais. Na doutrina pátria, porém, Fensterseifer ${ }^{89}$ diverge do entendimento de Nabais nesse ponto, sustentando posição favorável à abertura material a deveres fundamentais, mesmo que não previstos de forma expressa ou implícita no texto constitucional, em função da possibilidade de se reconhecer um novo dever, conexo ou autônomo, a partir da abertura material que a Constituição brasileira assegura aos direitos fundamentais. A questão, porém, ganha contornos diversos no que se refere à possibilidade de reconhecer a abertura material a deveres fundamentais autônomos em sentido estrito, ou seja, aqueles que não mantêm qualquer conexão com o conteúdo de um direito fundamental, justamente pelo fato de a abertura material, no sistema constitucional brasileiro, se dar a direitos fundamentais.

Outro traço significativo do regime jurídico geral dos deveres fundamentais, um tanto quanto controverso, é o da aplicabilidade indireta ou mediata dos deveres fundamentais. Saliente-se, por oportuno: a aplicabilidade direta ou imediata dos direitos fundamentais restou consagrada no ordenamento jurídico-constitucional brasileiro, no artigo $5^{\circ}, \S 1^{\circ}$, da Constituição da República. Contudo, o referido princípio divide a doutrina no que se refere aos deveres fundamentais, com a notável predominância do entendimento de sua inaplicabilidade para esse regime.

Para Dimoulis e Martins ${ }^{90}$ os deveres fundamentais possuem uma "estrutura bifásica", na qual cumpre à Constituição enunciá-los e à lei infraconstitucional concretizá-los. Assim, a tese da aplicabilidade imediata não possui valor prático, pois a vagueza dos termos que geralmente são empregados na definição constitucional de deveres fundamentais não lhes assegura exigibilidade sem uma regulamentação específica. Aliás, para Nabais ${ }^{91}$, independentemente do grau de concretização normativa de que disponham na Constituição, os deveres fundamentais

\footnotetext{
${ }^{89}$ FENSTERSEIFER, Tiago. Direitos fundamentais e proteção do ambiente: a dimensão ecológica da dignidade humana no marco jurídico-constitucional do Estado Socioambiental de Direito. Porto Alegre: Livraria do Advogado, 2008, p. 203.

${ }^{90}$ DIMOULIS, Dimitri; MARTINS, Leonardo. Deveres Fundamentais. In: LEITE, George Salomão; SARLET, Ingo Wolfgang; CARBONELL, Miguel (Coords.). Direitos, deveres e garantias fundamentais. Salvador: Juspodvium, 2011, p. 335.

${ }^{91}$ NABAIS, José Casalta. O dever fundamental de pagar impostos: contributo para a compreensão do estado fiscal contemporâneo. Coimbra: Almedina, 2009, p. 155.
} 
ISSN 1981-3694

(DOI): $10.5902 / 1981369438399$

"carecem sempre da intervenção do legislador para estabelecer as formas e os modos do seu cumprimento e a sancionação do correspondente não cumprimento". Ainda, na visão do autor, os preceitos consagradores de deveres fundamentais assemelham-se aos que consagram direitos fundamentais sociais "na medida em que estes se consubstanciam em direitos dos particulares a prestações sociais (de carácter material ou jurídico) do Estado, as quais, dada a sua natureza,

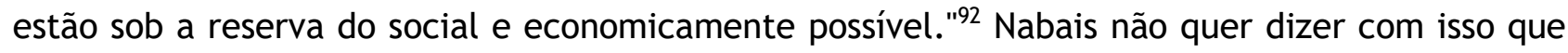
os preceitos constitucionais relativos aos deveres estejam desprovidos de qualquer força ou eficácia jurídica. Absolutamente não, afinal se tratam de normas jurídico-constitucionais dotados de uma específica eficácia jurídica, qual seja, a de consagrar posições jurídicas subjetivas passivas aos indivíduos. Tal conclusão, contudo, não afasta a necessidade de conformação legal "necessária à sua concretude conteudística e/ou sancionação."93

Semelhante é a posição de Sarlet ${ }^{94}$, para quem os deveres fundamentais podem ter aplicabilidade imediata dependendo do caráter da norma jurídico-constitucional fundamentadora. Obviamente que o autor está a se referir à hipótese de a norma constitucional consagradora do dever fundamental ter concretizado na plenitude o conteúdo desse dever, bem como a sanção para o seu descumprimento. Mas reconhece o autor que tanto no âmbito jurídicoconstitucional lusitano, quanto no âmbito jurídico-constitucional alemão, onde a temática tem sido mais desenvolvida pela doutrina, prevalece a tese de que os deveres fundamentais são apenas indiretamente aplicáveis e dependem de regulamentação infraconstitucional, diversamente do que ocorre com o regime jurídico geral dos direitos fundamentais.

\section{CONCLUSÃO}

Os deveres fundamentais constituem, uma categoria jurídico-constitucional própria, dotada de autonomia estrutural e funcional. Essa autonomia enquanto categoria jurídicoconstitucional decorre do fato de serem os deveres fundamentais expressões de valores ou interesses comunitários constitucionalmente reconhecidos.

Muitas vezes os deveres fundamentais podem ter seu conteúdo associado ou conexo a direitos fundamentais. Contudo, nem por isso, deixam de representar uma realidade jurídica

\footnotetext{
92 Ibidem, p. 149.

93 Ibidem, p. 160.

94 SARLET, Ingo Wolfgang. A eficácia dos direitos fundamentais: uma teoria geral dos direitos fundamentais na perspectiva constitucional. 10. ed. Porto Alegre: Livraria do Advogado Editora, 2010, p. 230.
} 
ISSN 1981-3694

(DOI): $10.5902 / 1981369438399$

autônoma. Aliás, são os valores comunitários, típicos de um Estado Social, que fundamentam a autonomia dos deveres fundamentais, valores estes que se contrapõem aos interesses individuais que se afirmam na figura dos direitos fundamentais.

Os deveres fundamentais, contudo, integram, no plano dogmático, a categoria dos direitos fundamentais em sentido amplo, notadamente pela vinculação que guardam com a dimensão objetiva dos direitos fundamentais. Essa vinculação, porém, diz respeito apenas aos valores comunitários que os fundamentam e consagram, mas não aos desdobramentos jurídicos que decorrem de ambos, notadamente porque a dimensão objetiva dos direitos fundamentais acarreta uma mais-valia jurídica à dimensão subjetiva dos próprios direitos fundamentais e essa mais valia gerada. A eficácia irradiante dos direitos fundamentais; a eficácia horizontal dos direitos fundamentais; os deveres de proteção do Estado; e as consequências nos planos organizacional e procedimental, não se confunde com os deveres fundamentais.

Há, contudo, entre ambos, uma conexão funcional. Os deveres fundamentais acarretam limitações na esfera de liberdade dos indivíduos e podem servir de fundamento para uma interpretação restritiva do conteúdo de um direito fundamental, a qual, como visto, jamais poderá ultrapassar o "limite dos limites", ou seja, violar o núcleo essencial do direito fundamental restringido.

Os deveres fundamentais são deveres tipicamente constitucionais, ou seja, seu fundamento jurídico reside na Constituição, sendo necessária uma previsão expressa ou implícita no texto constitucional para seu reconhecimento. O que poderia ser visto como uma fragilidade, é, na verdade, uma proteção contra eventuais intervenções dos poderes públicos na esfera jurídica dos indivíduos. Os deveres fundamentais são posições jurídicas passivas dos particulares em face do Estado e da coletividade em geral. Implicam, portanto, obrigações de conduta positivas ou negativas aos particulares. Diferenciam-se, pois, das demais posições jurídicas passivas constitucionalmente impostas aos indivíduos, como ocorre com os deveres correlativos de direitos fundamentais (deveres de abstenção ou não perturbação a esfera do direito fundamental alheio).

Justamente por investirem os indivíduos em posições subjetivas que vão se constituir em obrigações de conduta com conteúdo positivo ou negativo, os deveres fundamentais são também posições jurídicas subjetivas e individuais, já que destinadas aos indivíduos. Isso não impede ou inviabiliza, contudo, que as pessoas jurídicas, mesmo de natureza pública, venham a ser reconhecidas como destinatárias de deveres fundamentais, desde que compatíveis com sua natureza. Caracterizam-se também por sua universalidade, mesmo que alguns deveres 
ISSN 1981-3694

(DOI): $10.5902 / 1981369438399$

fundamentais possam destinar-se, por sua natureza, a determinados sujeitos específicos. São, ainda, verdadeiras cláusulas pétreas, ou seja, posições jurídicas rígidas, permanentes e essenciais, não sujeitas à restrição injustificada de conteúdo ou mesmo supressão nem mesmo em sede de revisão constitucional. Isso se deve, em essência, ao seu fundamento lógico: a dignidade da pessoa humana. Logo, na perspectiva jurídico constitucional brasileira, a vedação contida no art. $60, \S 4^{\circ}$, IV, da CF/88, aplica-se integralmente ao seu regime jurídico dos deveres fundamentais.

\section{REFERÊNCIAS}

ALEXY, Robert. Teoria dos Direitos Fundamentais. Trad. de Virgílio Afonso da Silva. São Paulo: Malheiros, 2008.

ANTUNES, Tiago. Ambiente: Um direito, mas também um dever. In: PINHEIRO, Luís de Lima; VICENTE, Dário Moura; MIRANDA, Jorge (Coords.). Estudos em memória do Professor Doutor Antônio Marques dos Santos, v. II. Coimbra: Almedina, 2005, p. 645-662.

ÁVILA, Humberto. Teoria dos Princípios: da definição à aplicação dos princípios jurídicos. 6. ed. São Paulo: Malheiros, 2006.

BARROSO, Luís Roberto. Interpretação constitucional como interpretação específica. In: CANOTILHO, J. J. Gomes; MENDES, Gilmar F.; SARLET, Ingo W.; STRECK, Lenio L. (Coords.). Comentários à Constituição do Brasil. São Paulo: Saraiva/Almedina, 2013, p. 91-96.

BASSO, Joaquim. Notas sobre o regime jurídico dos deveres fundamentais no ordenamento jurídico brasileiro. Revista Direito UFMS, v. 1, n. 2, Campo Grande, MS, 2016, p. 87-108.

BELCHIOR, Germana Parente Neiva. Hermenêutica jurídica ambiental. São Paulo: Saraiva, 2011.

CANOTILHO, José Joaquim Gomes. Direito Constitucional e Teoria da Constituição. 7. ed. Coimbra: Almedina, 2003.

DIMOULIS, Dimitri; MARTINS, Leonardo. Deveres Fundamentais. In: LEITE, George Salomão; SARLET, Ingo Wolfgang; CARBONELL, Miguel (Coords.). Direitos, deveres e garantias fundamentais. Salvador: Juspodvium, 2011.

DWORKIN, Ronald. Levando os direitos a sério. Trad. Nelson Boeira. 3. ed. São Paulo: Martins Fontes, 2010.

FENSTERSEIFER, Tiago. Direitos fundamentais e proteção do ambiente: a dimensão ecológica da dignidade humana no marco jurídico-constitucional do Estado Socioambiental de Direito. Porto Alegre: Livraria do Advogado, 2008.

GABARDO, Emerson. Interesse público e subsidiariedade. Belo Horizonte: Fórum, 2009. 
GOMES, Carla Amado. Risco e modificação do acto autorizativo concretizador de deveres de protecção do ambiente. 2007. 564 f. Tese de Doutorado em Ciências Jurídico-Políticas, Faculdade de Direito. Universidade de Lisboa, Lisboa.

MEDEIROS, Fernanda Luiza Fontoura de. Direito dos Animais. Porto Alegre: Livraria do Advogado, 2013.

MEDEIROS, Fernanda Luiza Fontoura de. Meio ambiente: direito e dever fundamental. Porto Alegre: Livraria do Advogado, 2004.

MIRANDA, Jorge. Manual de Direito Constitucional, Tomo IV - Direitos Fundamentais, 3. ed. Coimbra: Almedina, 2000.

MOREIA NETO, Diogo de Figueiredo. Mutações do direito administrativo. Rio de Janeiro: Renovar, 2000, p. 20.

NABAIS, José Casalta. A face oculta dos direitos fundamentais: os deveres e os custos dos direitos. Revista da AGU, Brasília, v.1, 2001, p. 73-92.

NABAIS, José Casalta. 0 dever fundamental de pagar impostos: contributo para a compreensão do estado fiscal contemporâneo. Coimbra: Almedina, 2009.

PECES-BARBA MARTÍNEZ, Gregório. Los deberesfundamentales. Doxa:cuadernos de filosofíadelderecho. n. 4, 1987, p. 329-341.

PIEROTH, Bodo; SCHLINK, Bernhard. Direitos Fundamentais. Trad. António Francisco de Sousa e António Franco. São Paulo: Saraiva, 2012.

RAMMÊ, Rogério Santos. O dever fundamental ecológico e a proteção dos serviços ecossistêmicos. Curitiba: Editora Appris, 2019.

SARLET, Ingo Wolfgang. A eficácia dos direitos fundamentais: uma teoria geral dos direitos fundamentais na perspectiva constitucional. 10. ed. Porto Alegre: Livraria do Advogado Editora, 2010.

SARLET, Ingo Wolfgang; FENSTERSEIFER, Tiago.Direito constitucional ambiental: constituição, direitos fundamentais e proteção do ambiente. 3. ed. São Paulo: Revista dos Tribunais, 2013.

SOUZA, Felipe Oliveria de. O raciocínio jurídico entre princípios e regras. In: Brasília, a. 48, n. 192, 2011, p. 95-109.

TORRES, Ricardo Lobo. Tratado de direito constitucional, financeiro e tributário: valores e princípios constitucionais tributários. Rio de Janeiro: Renovar, v. II, 2005.

TORRES, Sílvia Faber. 0 princípio da subsidiariedade no direito público contemporâneo. Rio de Janeiro: Renovar, 2001.

VIEIRA DE ANDRADE, José Carlos. Os direitos fundamentais na Constituição Portuguesa de 1976. 5. ed. Coimbra: Almedina, 2012. 
ISSN 1981-3694

(DOI): $10.5902 / 1981369438399$

VIEIRA, Pedro Gallo; PEDRA, Adriano Sant'Ana. O rol de deveres fundamentais na Constituição como numerusapertus. Derecho y Cambio Social, n. 31, 2013, p. 1-11. Disponível em: https://www.derechoycambiosocial.com/revista031/O_ROL_DE_DEVERES_FUNDAMENTAIS.pdf. Acesso em: 12 set. 2020.

VILHENA, Maria do Rosário. 0 princípio da subsidiariedade no direito comunitário. Coimbra: Almedina, 2002.

Recebido em: 01.06.2019 / Revisões requeridas em: 26.06.2020 / Aprovado em: 02.09.2020 / Publicado em: 01.10.2020

\section{COMO FAZER REFERÊNCIA AO ARTIGO (ABNT):}

RAMMÊ, Rogério Santos. O Regime Jurídico-Constitucional dos Deveres Fundamentais. Revista Eletrônica do Curso de Direito da UFSM, Santa Maria, RS, v. 15, n. 3, e38399, set./dez. 2020. ISSN 1981-3694. DOI: http://dx.doi.org/10.5902/1981369438399. Disponível em:

https://periodicos.ufsm.br/revistadireito/article/view/38399 Acesso em: dia mês. ano.

Direitos autorais 2020 Revista Eletrônica do Curso de Direito da UFSM

Editores responsáveis: Rafael Santos de Oliveira e Angela Araujo da Silveira Espindola

\section{(c) (†) $\odot$

Esta obra está licenciada com uma Licença Creative Commons Atribuição-NãoComercial-SemDerivações 4.0 Internacional.

\section{SOBRE O AUTOR}

\section{ROGÉRIO SANTOS RAMMÊ}

Doutor em Direito pela PUCRS. Mestre em Direito Ambiental pela UCS. Especialista em Direito Ambiental pela ULBRA. Professor do Curso de Direito do Centro Universitário Metodista IPA. Coordenador do Projeto de Extensão Direitos Animais no Centro Universitário Metodista IPA. Professor convidado nos Cursos de Especialização em Direito Público e em Direito Ambiental e Sustentabilidade da PUCRS. Membro da Comissão de Direito Ambiental da OAB/RS. Coordenador e professor do Curso de Aperfeiçoamento em Direitos Animais na Escola Superior da Advocacia (ESA) da OAB/RS (1 ${ }^{\mathrm{a}}$ e $2^{\mathrm{a}}$ ed. /2019). Autor de livros e artigos nas áreas do direito ambiental e direito animal. Criador da primeira disciplina de Direito Animal a ser ofertada em um curso de Direito em Porto Alegre/RS. Advogado e consultor jurídico no escritório Rammê Direito Ambiental e Animal. 